
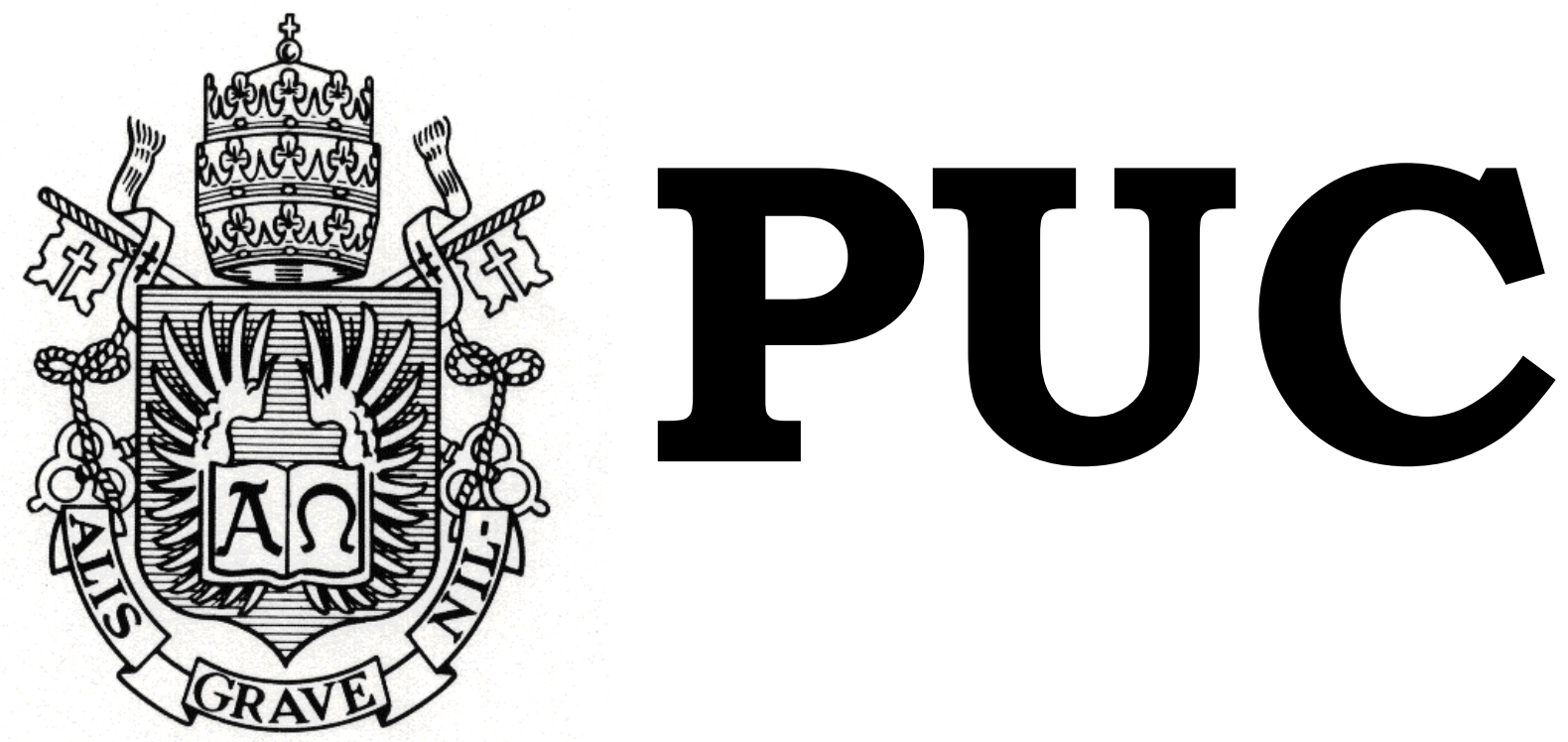

DEPARTAMENTO DE DIREITO

\title{
A INTERVENÇÃO DO ESTADO NO DOMÍNIO ECONÔMICO
}

\author{
por \\ GABRIELA ASSIS ABDALLA
}

ORIENTADOR: PEDRO PAULO SALLES CRISTOFARO

2012.2

PONTIFÍCIA UNIVERSIDADE CATÓLICA DO RIO DE JANEIRO

RUA MARQUÊS DE SÃO VICENTE, 225 - CEP 22453-900

RIO DE JANEIRO - BRASIL 


\title{
A INTERVENÇÃO DO ESTADO NO DOMÍNIO ECONÔMICO
}

\author{
por \\ GABRIELA ASSIS ABDALLA \\ Monografia apresentada ao \\ Departamento de Direito da \\ Pontificia Universidade Católica \\ do Rio de Janeiro (PUC-Rio) como \\ requisito parcial para obtenção \\ do título de Bacharel em Direito
}

Orientador: Pedro Paulo Salles Cristofaro

2012.2 
Dedico esta obra ao meu avô, Miguel Abdalla Netto (in memoriam), meu eterno incentivador; ao meu pai, Luciano, à minha mãe, Lucia Helena, e ao meu irmão, Daniel, minhas fontes inesgotáveis de carinho $e$ suporte. 
Meus sinceros agradecimentos

Ao meu melhor amigo, João Paulo Azeredo da Rosa, pela leitura crítica de alguém leigo no tema e por me acompanhar em mais um capítulo da minha vida;

Aos queridos Fernanda Bortolini, pelas dicas e vivência de Direito Administrativo, e Felipe Cozer, por todas as opiniões contrárias e pelos incansáveis debates sobre o tema;

Ao Pinheiro Neto Advogados, pela rica biblioteca e experiência jurídica ímpar;

Aos meus "chefes", Marcos Saldanha Proença e Décio Pio Borges de Castro, pelos ensinamentos da vida e de Direito; $e$

Ao Professor Pedro Paulo Salles Cristofaro, que motivou meu interesse pelo tema e foi paciente e atencioso na orientação e crítica do trabalho. 


\section{Resumo:}

O presente trabalho possui como escopo analisar as modalidades e os limites à intervenção do Estado no domínio econômico, buscando as raízes históricas da formação do Estado Executor e Estado Regulador. Analisaremos os princípios constitucionais da Ordem Econômica contrapondo-os e mostrando a sua pertinência sobre a atividade econômica. Em seguida, estudaremos os fundamentos constitucionais da atividade intervencionista do Estado sobre e no domínio econômico, diferenciando os seus aspectos jurídicos. Por fim, analisaremos como são aplicadas de forma concreta as modalidades de intervenção do Estado no domínio econômico e as decisões do Supremo Tribunal Federal sobre cada caso.

Palavras-Chave: Estado; Intervenção; Domínio econômico; Direito econômico; Princípios constitucionais econômicos; Modalidades interventivas. 
1. INTRODUÇÃO

2. A HISTÓRIA DA INTERVENÇÃO DO ESTADO NA ECONOMIA MUNDIAL

3. A INTERVENÇÃO DO ESTADO NA ECONOMIA NO BRASIL 17

4. PRINCÍPIOS CONSTITUCIONAIS ECONÔMICOS 28

5. FORMAS DE ATUAÇÃO DO ESTADO NA ECONOMIA 36

5.1. ESTADO EXECUTOR 39

5.2. ESTADO REGULADOR 44

6. CLASSIFICAÇÃO DAS MODALIDADES INTERVENTIVAS 50

6.1. INTERVENÇÃO DIRETA

6.1.1. INTERVENÇÃO POR ABSORÇÃO

6.1.2. INTERVENÇÃO POR PARTICIPAÇÃO

6.2. INTERVENÇÃO INDIRETA 58

6.2.1. INTERVENÇÃO POR DIREÇÃO 59

6.2.2. INTERVENÇÃO POR INDUÇÃO 62

7. CONCLUSÃO 67

BIBLIOGRAFIA $\quad 69$ 


\section{INTRODUÇÃO}

O papel do Estado e a sua intervenção na economia são, certamente, temas que atravessam a história e que, até hoje, são amplamente questionados. O debate é um tanto mais caloroso quanto mais o órgão estatal interfere na esfera privada.

Essa atuação, por sua vez, suscita a reflexão sobre temas muito interessantes que acabam sempre deixando à mostra a tênue linha que divide o campo de domínio privado e o de domínio público.

No campo do domínio privado observamos que o setor econômico responde por grande parte das relações entre os particulares. Desde os tempos mais remotos, os indivíduos realizavam trocas e se organizavam em pequenas sociedades. O comércio e o mercado são partes integrantes da sociedade, da qual não se dissociam. $\mathrm{O}$ fato das pessoas responderem a impulsos econômicos e de suas vidas serem diretamente afetadas por qualquer desequilíbrio no mercado faz com que o Estado observe este setor de forma mais atenta, passando a se debruçar sobre ele.

Daí, a livre iniciativa, pilar das liberdades econômicas, ser tão importante. É ela que garante a liberdade de comércio em sentido amplo, garante que o indivíduo poderá desempenhar o seu papel dentro do mercado e assim desenvolver suas atividades econômicas de forma livre.

Diante da relevância do setor econômico para a sociedade entendemos ser de relevante interesse o estudo da atuação do Estado neste este setor. O objetivo deste trabalho, portanto, será o de analisar o papel do Estado na ordem econômica, as suas formas de atuação e os seus limites, pautando-se sempre nos princípios da Constituição de 1988, sem pretender exaurir o tema. 
Para iniciar essa análise, recorreremos, primeiramente, ao estudo da evolução histórica da intervenção estatal sobre a economia, tendo em vista que o atual modelo de Estado reflete, em grande parte, os resultados das experiências históricas vividas no passado.

Uma vez que o panorama geral estiver sedimentado, passaremos a estudar como os ideais liberais e intervencionistas refletiram no papel assumido pelo Estado brasileiro desde o império até a atual Constituição que dispõe de um título próprio para a Ordem Econômica e Social.

Os princípios constitucionais econômicos, como norteadores da ordem econômica, serão cuidadosamente descritos em seguida e são prérequisitos para o estudo das formas de atuação do Estado na economia.

Por fim, tentaremos descrever brevemente as modalidades de intervenção do Estado no domínio econômico trazendo situações reais para que possamos refletir, no caso concreto, sobre os limites do Estado em cada uma das modalidades. 


\section{A HISTÓRIA DA INTERVENÇÃO DO ESTADO NA ECONOMIA MUNDIAL}

A dicotomia aparentemente lógica entre a intervenção estatal e a livre iniciativa possui raízes profundas na história das sociedades. As origens dessa dicotomia remontam ao século XVIII quando a teoria do liberalismo clássico reinava absoluta. $\mathrm{O}$ pensamento filosófico embasado por pensadores como Adam Smith, no campo do liberalismo econômico, e John Locke, no liberalismo político (Laissez-faire), pregava a separação entre a atividade econômica e a política.

De acordo com as ideias liberais de Adam Smith, caberia ao Estado três deveres: (i) o de proteger a sociedade da invasão por outros estados; (ii) o de proteger cada membro da sociedade da injustiça e da opressão de qualquer outro membro; e (iii) o de praticar e manter determinadas políticas e obras públicas que, por possuírem baixa (ou nenhuma) perspectiva de lucro, não seriam interessantes para os indivíduos isoladamente, mas que a sua realização fosse relevante para a sociedade como um todo.

Segundo a teoria do liberalismo econômico, as forças econômicas seguem um curso natural, regidas principalmente pela lei da oferta e da procura e pela prática da livre concorrência. O liberalismo adota uma economia de mercado segundo a qual não há um planejador central cuidando do desenvolvimento econômico, mas sim um conjunto de decisões isoladas de famílias e empresas que, interagindo no mercado, guiam suas decisões pelo preço e por seus interesses próprios.

A premissa de que todos os indivíduos buscam apenas a satisfação de seus interesses sem se ater ao bem coletivo garante resultados desejáveis, quando observadas do plano macroeconômico. A "mão invisível” conduz a economia tendo o preço como instrumento já que ele se ajusta de acordo 
com a oferta e a demanda para alcançar resultados que maximizem os lucros e o bem-estar da sociedade.

O papel do Estado nesse modelo econômico seria o de garantir a propriedade privada, sem a qual não há garantia dos bens a serem negociados, e as condições mínimas do livre mercado.

Ao lado do desenvolvimento do liberalismo econômico, a Revolução Francesa (1789 - 1799) marca a histórica com ideais filosóficos liberais liberdade, igualdade e fraternidade - trazendo a concepção de que uma das finalidades do Estado era a proteção dos direitos individuais contra os abusos da autoridade. Em contraposição ao período monárquico, a Revolução Francesa, com a influência de ideais do liberalismo econômico, deu início ao modelo de Estado Liberal do século XIX.

Devemos lembrar que a Revolução Francesa, muito caracterizada pela movimentação política de uma classe burguesa contra o monarca, tornava ainda mais difícil a adoção de qualquer intervenção estatal. As características do Estado ainda se confundiam com as do monarca e a intervenção representava um retrocesso ao regime anterior.

Para os liberais clássicos, cada indivíduo deveria ter a liberdade de promover seus próprios interesses e ninguém melhor que ele para avaliálos, sendo totalmente desnecessária a ingerência estatal sobre este aspecto. Para estes pensadores a relação entre particulares poderia se autorregular, e eles alcançariam um ordenamento quase perfeito a partir da própria lógica do mercado. O lema era "laissez faire, laissez-passer" (deixai fazer, deixai passar). Nesse sistema, a atuação do Estado não incidiria sobre a esfera privada, devendo garantir a propriedade privada e permanecer como mero observador da organização autônoma dos indivíduos.

Ocorre que este pensamento não demorou a ser criticado e posto à prova. A ideia do liberalismo econômico radical possuía falhas que diziam 
respeito à própria organização do sistema. Nos dizeres de Mankiw " "a mão invisível é poderosa, mas não é onipotente". Constatou-se a existência de determinadas situações em que o mercado não era capaz de, por si só, alocar os recursos de forma eficiente (o fenômeno economicamente conhecido como "falha de mercado").

Uma das hipóteses para criação da falha de mercado se configurava na concentração do poder de mercado - quando um único agente (agindo individualmente ou em grupo) ganhava tanto poder que era capaz de influenciar os preços praticados pelo mercado, levando à supressão da concorrência. Diante desse contexto, o Estado começou a ser chamado a intervir na economia de modo a garantir a própria existência da ordem capitalista e da economia de mercado.

Além dos fatores econômicos, do ponto de vista político, o final do século XIX foi marcado pela eclosão das escolas socialistas e, especialmente em 1848, pela publicação do Manifesto Comunista de Karl Marx, com ideais contrários ao liberalismo.

A revolução industrial, apesar de ter trazido um enorme desenvolvimento científico, deixou à mostra as diferenças entre a burguesia e o proletariado. $\mathrm{O}$ desenvolvimento da indústria provocou a migração de muitos trabalhadores para os grandes centros urbanos em busca de emprego. $\mathrm{O}$ espaço urbano inchado e sem infraestrutura não fornecia condições dignas, favorecendo inclusive a proliferação de doenças.

A longa jornada de trabalho, os baixos salários, as condições precárias de segurança nas fábricas e a inserção cada vez maior de mulheres e crianças dentro do ambiente industrial motivou a revolução da classe operária no início do século XIX. As questões e problemas reais dos trabalhadores começaram a ser levados para o plano político.

\footnotetext{
${ }^{1}$ MANKIW, Gregory N. Introdução a Economia. São Paulo: Pioneira Thomson, 2011. p.10-11.
} 
O Cartismo (1838-1848), na Inglaterra, a Revolução de 1848 e a Comuna de 1871, na França, são movimentos caracterizados pela tentativa de inserção dos representantes das massas operárias no contexto político. Os movimentos políticos questionavam o sistema então vigente $\mathrm{e}$ buscavam, além de uma maior representação política, a garantia de que o bem-estar social de fato chegaria para todos os integrantes da sociedade. Era o momento de reivindicar melhores condições de trabalho, igualdades políticas e eleitorais, melhor distribuição de riquezas, quesitos que só poderiam se concretizar através de um Estado mais atuante.

Ressalte-se que nesse momento da história a intervenção do Estado começa a ser aceita de uma forma menos negativa. A intervenção não é um retrocesso, mas sim a possibilidade de ver o ideal de igualdade se concretizar na vida dos operários.

Para além da revolução das massas operárias, os países enfrentaram, já no início do século XX, a necessidade de voltar os seus esforços para a Primeira Guerra Mundial. A economia de guerra e a mobilização das atividades econômicas para garantir o poder bélico do Estado provocou indiretamente o alargamento das atribuições estatais.

Interessante observar os dizeres de VIGORITA, citados por VENÂNCIO FILHO, a respeito dos efeitos da guerra sobre o regime do liberalismo:

"a Primeira Guerra Mundial rompe a tradição do liberalismo econômico, acelerando violentamente a ação dos fatores desagregadores. De fato, tal guerra: a) dilata desmesuradamente as exigências de armamento e aprovisionamento, demonstrando a necessidade do controle integral e coativo da vida econômica; b) em virtude disso, constitui uma experiência concreta da total disciplina pública da economia, assumido como modelo de futuros objetivos autoritários de política econômica; e ao mesmo tempo cria hábitos e métodos dirigistas dificilmente anuláveis; c) provoca excessos dimensionais e distribuições erradas na industrialização, com predisposição à ruínca por falta e capital e de demanda, e consequente 'absorção' estatal para evitar a crise; d) fraciona o mercado internacional pelo surgimento de novos Estados (..); e) provoca o desenvolvimento numérico e o despertar classicista das massas operárias, de quem acresce o peso político e a força organizatória, colocando em posição de 
condicionar a tradicional supremacia das antigas classes dirigentes e de exigir a revisão em sentido social do intervencionismo"2

Do ponto de vista da produção jurídica, o período do final da Primeira Guerra Mundial foi especialmente importante pela promulgação da Constituição Mexicana de 1917 e da Constituição de Weimar de 1919. Ambas as Cartas consagraram direitos sociais e deram início a uma fase de constitucionalização do Estado Social de Direito, positivando no texto constitucional aspirações sociais reivindicadas nas revoluções da classe operária promovidas ao status de princípios constitucionais.

No plano econômico, o contexto do pós-guerra ainda foi agravado pelo acometimento da Grande Depressão na década de 30, e novos estudos econômicos surgiram buscando soluções para a crise e teorias para evitar novos colapsos, atribuídos a falhas produzidas por um mercado livre. Esses estudos, em especial o de John Maynard Keynes, embasaram cientificamente o surgimento do Estado Intervencionista ou o Estado Social.

Para Keynes, a teoria econômica clássica explicava os efeitos de longo prazo das políticas econômicas e, por isso, não cuidava dos eventuais picos de crise acreditando que eles seriam sanados no longo prazo. Keynes percebe que é nos momentos de crise que o Estado é chamado a intervir de forma mais vigorosa, tanto pelos menos desfavorecidos, que nessas épocas ficam desempregados, como pelo empresário que não tem demanda para gerar seus lucros. Tendo essa premissa, Keynes introduz o ideal de que o Estado, atuando de forma organizada, é capaz de estabilizar, estimular e dirigir o rumo de sua economia sem descambar para um regime autoritário, podendo a economia e a política conviver de forma harmoniosa.

\footnotetext{
${ }^{2}$ VIGORITA, Vincenso Spagnuolo. L'Iniziativa Economica Privata nel Dirito Publico. Napoli, 1959, pp. 170-172 apud FILHO, Alberto Venâncio. A Intervenção do Estado no Domínio Econômico. Rio de Janeiro: Renovar, 1968. p. 11.
} 
A teoria econômica de Keynes reconcilia a iniciativa privada e a atuação estatal, possibilitando que o Estado passasse a interferir e induzir o rumo da economia sem dirigismo - buscando satisfazer os interesses coletivos. Para Dênio Nogueira ${ }^{3}$, citado por Alberto Venâncio Filho, a teoria de Keynes construiu o ideal da economia de bem-estar social.

No período que sucede a Grande Depressão, dois regimes totalitários emergiram: o nazista e o fascista. Foram duas experiências totalmente antiliberais, em que o Estado controlava diretamente toda a ordem econômica, e contemporâneas ao regime socialista da União Soviética, com características também voltadas para o alargamento do poder do Estado.

Nos Estados Unidos, inspiradas na teoria de Keynes, as medidas "anticrise", como os planos econômicos propostos por Roosevelt, J. Kennedy e L. Johnson, respectivamente, o "New Deal", a "Nova Fronteira" e a "Grande Sociedade", também evidenciavam o aumento do papel do Estado na regulação da economia.

O novo modelo de Estado permitiria a intervenção no campo econômico para assegurar o seu crescimento equilibrado, adotando um sistema em que o interesse público limita os ideais do regime capitalista. Interessante perceber que, na perspectiva desse novo modelo, a atuação estatal visa a garantir direitos constitucionais, sendo um deles o direito à assistência, como bem descrito por Pedro Lenza ao citar a obra de Wilenski:" "a assistência prestada pelo Estado do bem-estar ('Welfare State'), ou Estado assistencial, não é oferecida como caridade, mas sim como direito político".

O Estado passa, então, à fase do dirigismo econômico, se propondo a, através da regulação e fiscalização do mercado, proporcionar uma

\footnotetext{
${ }^{3}$ FILHO, Alberto Venâncio. A Intervenção do Estado no Domínio Econômico. Rio de Janeiro: Renovar, 1968. p. 12.

${ }^{4}$ LENZA, Pedro. Direito Constitucional Esquematizado. 15 ed. São Paulo: Saraiva, 2011. p. 1138.
} 
distribuição de renda mais igualitária e amenizar as consequências de regras exclusivamente liberalistas/capitalistas, vistas como danosas à sociedade.

Com este novo sistema, diversas regras jurídicas reguladoras da ordem econômica passaram a existir, ganhando tanta importância que sentiu-se a necessidade de constitucionalizá-las como princípios norteadores daquele sistema jurídico. As cartas constitucionais daquela época ou não abarcavam normas econômicas ou estabeleciam apenas a observância aos institutos clássicos do direito de propriedade e da autonomia da vontade privada - medidas lógicas visto que o capitalismo pregava por sua autorregulação e pela mínima intervenção estatal.

Estes princípios clássicos, entretanto, já não eram mais suficientes para regular a atividade econômica. $\mathrm{O}$ constituinte viu a necessidade de incluir no texto constitucional a adoção do modelo capitalista com a finalidade de garantir a todos a existência digna, de acordo com a justiça social. Criou-se espaço para a intervenção do Estado, vista como uma forma de garantir esses preceitos e a manutenção do próprio modelo capitalista, além de tentar solucionar as supostas falhas de mercado.

$\mathrm{Na}$ maioria dos países ocidentais, o direito de propriedade, a liberdade de comércio e a autonomia da vontade privada não foram suprimidos nesse processo, mas foram mitigados frente ao interesse social, de modo que a intervenção estatal servisse para coibir o abuso no exercício desses direitos.

Na prática, para intervir na ordem econômica o Estado precisou se municiar de técnicas antes próprias do empresário. Como anota José dos Santos Carvalho Filho citando uma obra de Debbasch:

“(...) a intervenção do Estado na ordem econômica se consubstanciou e se ampliou através de diversas formas e ensejou algumas técnicas especiais, entre estas a criação e a gestão pelo Estado de empresas industriais e comerciais. Por intermédio delas, passou a ter maior proximidade com os setores privados do 
capital e maior eficiência no controle de condutas privadas prejudiciais à comunidade." 5

A adoção do modelo de Estado de Bem-Estar significou o acúmulo de funções e atividades diretas a serem exercidas pelo Estado. O Estado passou a assumir o papel de prestador ("Estado Provedor") garantindo condições de vida mínimas para a sociedade.

O saldo da intervenção estatal direta foi positivo representando melhorias para uma grande parcela da sociedade que antes não recebia esses benefícios. Em um estudo bem cuidadoso do tema, Marçal Justen Filho adota o critério da expectativa de vida para mostrar que adoção dessa posição ativa do Estado, de fato, alterou positivamente as condições de vida dos cidadãos. ${ }^{6}$

O problema é que a própria prestação de serviços gera custos que são integralmente suportados pelo Estado que, por sua vez, tem limitações orçamentárias advindas das contribuições fiscais que recebe. Em meados da década de 70, o Estado de Bem-Estar começou a dar sinais de que o modelo, da forma como estava sendo aplicado, gerava um grande endividamento do Estado e a ineficiência de diversas atividades. Para que continuassem prestando esses serviços, os Estados teriam que necessariamente aumentar sua arrecadação. Este fenômeno ficou conhecido como a "crise fiscal".

Países como Estados Unidos, França e Alemanha, apesar de terem modelos de "Estado de Bem-Estar" diferentes, experimentaram problemas, pela inviabilidade das atividades puramente provedoras do Estado e que culminaram na crise fiscal. Os altos gastos, a ineficiência do aparelho

\footnotetext{
${ }^{5}$ CARVALHO FILHO, José dos Santos. Manual de Direito Administrativo. 23 ed. Rio de Janeiro: Lumen Juris, 2010. p. 987.

${ }^{6}$ JUSTEN FILHO, Marçal. O Direito Regulatório. Interesse Público: Fórum. Belo Horizonte, n. 43, p. 19-40, 2007.
} 
estatal para fornecer serviços técnicos e de evolução tecnológica rápida fizeram com que o papel e o tamanho ideal de Estado fossem questionados.

O "Estado Regulador" surge nessa época e possui características próprias. Segundo Marçal Justen Filho:

"O Estado Regulador se peculiariza pelo compartilhamento entre Estado e sociedade da responsabilidade de promover a tão esperada 'revolução social'. Reconhece-se que a dimensão dos encargos necessários à concretização dos valores fundamentais supera os limites de possibilidade da atuação isolada do Estado. Por isso, a sociedade civil é convocada para particiar ativamente do desempenho de atividades necessárias à produção da igualdade substancial entre os cidadãos."

Esta forma de regulação e intervenção, como veremos mais adiante, vem sendo reformulada e adaptada de acordo com as necessidades de cada país. No Brasil, essa experiência é relativamente recente e possui reflexos de um contexto histórico próprio que vivemos e que será estudado no próximo capítulo.

\footnotetext{
${ }^{7}$ Ibidem, p. 24.
} 


\section{A INTERVENÇÃO DO ESTADO NA ECONOMIA NO BRASIL}

A evolução histórica da intervenção estatal no Brasil segue um rumo um pouco diferente do panorama mundial (leia-se, principalmente, europeu e americano). O Brasil, enquanto colônia de Portugal, era submetido a uma administração extremamente fiscalista que criava diversas formas de retenção de recursos na colônia para repassá-los a metrópole. O panorama do Brasil, no período colonial, era regido por um sistema mercantilista e por características típicas da colônia portuguesa, motivo pelo qual nosso país não passou pela fase do liberalismo econômico clássico.

Apenas em 1808, com a vinda da família real e a consequente transferência de todo o aparato administrativo para o Brasil, o desenvolvimento econômico e o processo de intervenção do Estado nas atividades do setor privado passou a ser mais perceptível, descaracterizando o ideal fiscalista.

Em $1^{\circ}$ de abril de 1808, D. João, no intuito de fomentar o desenvolvimento da colônia, institui a liberdade de comércio permitindo a livre instalação de fábricas e manufaturas. A redação do alvará dispunha como se segue:

"Permitte o livre estabelecimento de fabricas e manufacturas no Estado do Brazil. Eu o Principe Regente faço saber aos que o presente Alvará virem: que desejando promover e adiantar a riqueza nacional, e sendo um dos mananciaes della as manufacturas e a industria que multiplicam e melhoram e dão mais valor aos generos e productos da agricultura e das artes e augmentam a população dando que fazer a muitos braços e fornecendo meios de subsistencia a muitos dos meus vassallos, que por falta delles se entregariam aos vicios da ociosidade: e convindo remover todos os obstaculos que podem inutilisar e frustrar tão vantajosos proveitos: sou servido abolir e revogar toda e qualquer prohibição que haja a este respeito no Estado do Brazil e nos meus Dominios Ultramarinos e ordenar que daqui em diante seja licito a qualquer dos meus vassallos, qualquer que seja o Paiz em que habitem, estabelecer todo o genero de manufacturas, sem exceptuar alguma, fazendo os seus trabalhos em pequeno, ou em grande, como entenderem que mais lhes convem; para o que hei por bem derogar o Alvará de 5 de Janeiro de 1785 e quaesquer Leis ou Ordens que o contrario decidam, como se dellas 
fizesse expressa e individual menção, sem embargo da Lei em contrario." ${ }^{\prime}$

Em 1822 apesar de declarada a independência, a estrutura se mantém e o Império estende cada vez mais o seu controle sobre as atividades particulares - exigindo autorizações e tarifas protecionistas. Durante o período imperial começaram os trabalhos para elaboração do Código Comercial e da Lei de Terras que viriam a ser promulgados em 1850. Curiosamente, apesar da base econômica predominantemente agrária, a criação de normas administrativas nessa época é bastante rica.

Em 15 de novembro de 1889 o Império cai e é proclamada a República no Brasil. O então presidente, Deodoro da Fonseca, convoca eleições para a Assembleia Constituinte dando início aos esforços para a elaboração de uma nova constituição baseada em ideais liberais e positivistas.

A Constituição de 1891 estabelece um modelo federalista e limita a competência da União para atuar apenas na instituição de bancos emissores de moeda e na criação e manutenção de alfândegas, permanecendo fora das atividades estritamente econômicas. O Estado possui ainda o direito de legislar sobre viação férrea e navegação interior, sendo que a navegação de cabotagem será feita somente por navios nacionais.

Durante os primeiros anos da República, coube a Rui Barbosa o cargo de Ministro da Fazenda. No desempenho dessa atividade, Rui Barbosa preconizou um plano de industrialização na tentativa de modificar o modelo puramente cafeeiro vigente à época. Dentre as diversas medidas adotadas pelo ministro ressaltam-se: (i) a permissão para alguns bancos privados emitirem papel moeda; (ii) edição de leis facilitando o estabelecimento de sociedades anônimas; e (iii) novo regime alfandegário buscando proteger a nascente indústria brasileira.

\footnotetext{
${ }^{8}$ Alvará - de $1^{\circ}$ de Abril de 1808. Disponível em <http://www.planalto.gov.br >. Acesso em 6 de nov. 2012.
} 
Entretanto, o plano de industrialização e a crescente emissão de papel moeda resultaram em uma crise inflacionária sem medidas e os planos industrializantes não obtiveram o sucesso esperado. O país de base agrícola assim permaneceu virando suas preocupações para os interesses econômicos de proteção do café - o pilar da economia brasileira - frente ao mercado internacional. As primeiras medidas intervencionistas do Estado republicano brasileiro nasceram com o de controle de abastecimento e preço do café para proteger nosso maior produto das reviravoltas do mercado.

As consequências da Primeira Guerra Mundial desequilibraram ainda mais as economias do país, o que favoreceu a edição de normas tais como o Decreto 13.069 de 12 de junho de 1918 - conhecida pela criação do Comissariado de Alimentação Pública. O referido órgão controlava o estoque de alimentos essenciais e possuía poderes para tabelar seus preços, caso entendesse necessário.

O descompasso fático entre a intervenção real do Estado e os princípios constitucionais mais liberais resultou na emenda constitucional de 3 de setembro de 1926 que conferiu amplos poderes à União.

$\mathrm{O}$ modelo cafeeiro entrou em crise no início do século $\mathrm{XX}$ e foi agravado com o acometimento da Crise de 1929 que provocou alterações na taxa cambial e levaram a queda brutal nos preços do café, tornando insustentável o modelo protecionista brasileiro. O endividamento externo contraído no governo de Campos Salles (1898-1902) - que apostava na valorização do café - tornou ainda mais difícil a situação econômica do país que se sustentava numa base artificial de regulação dos preços do café.

Em 1930, com a revolução política da Aliança Liberal e a chegada de Getúlio Vargas a presidência, foi possível perceber uma efetiva modificação no plano econômico brasileiro. Foi de Vargas a tarefa de 
realizar a transição do sistema oligárquico - primordialmente agrário - para o Estado progressista. Com esse propósito, Vargas concedeu diversos incentivos para investimentos em bens de capital e instituiu planos de incentivo à industrialização.

O país passou a enfrentar os problemas da economia moderna - leiase, os problemas da guerra e das condições precárias da vida dos trabalhadores - por isso, a criação dos ministérios do Trabalho, Educação e Saúde, foi importante para tentar garantir a prestação de serviços a essa população.

Foi também durante o Governo Provisório (1930-1934) que começaram as movimentações legislativas para edição dos códigos de minas, águas e energia. Os códigos, mais do que regular a matéria, deram ao Estado mais poderes sobre o desenvolvimento dessas atividades.

Já no final do Governo Provisório, convocou-se uma nova Assembleia Constituinte. A Carta de 1934 foi promulgada em um contexto pós-guerra, marcada por um ideal redemocratizador e intolerante a regimes autoritários, tendo como molde as Constituições do México e de Weimar que, como mencionado anteriormente, adotaram o título "Da Ordem Econômica e Social", buscando resguardar o bem-estar social e a proteção das garantias individuais e sociais.

No Brasil, a Constituição de 1934 foi a primeira a adotar esta nova postura do Estado, estabelecendo um discurso intervencionista e inovador que introduziu os princípios da justiça social e da existência digna, garantindo a liberdade econômica dentro desses limites. A partir daí houve uma profunda mudança no papel assumido pelo Estado. Conforme assinala Celso Antônio Bandeira de Mello, o Estado passou a poder intervir no domínio econômico atuando (i) como sujeito ativo, assumindo participação direta nas atividades econômicas; (ii) através de medidas fomentadoras que 
incentivem a atividade privada e (iii) como agente regulador, disciplinando os comportamentos dos particulares, por intermédio do seu poder de polícia. ${ }^{9}$

Entretanto, o progresso trazido pela Constituição de 1934 não sobreviveu aos conflitos ideológicos daquela época e muito menos ao interesse militar de suprimir os movimentos comunistas existentes - mesmo que desorganizados e incipientes -, como a Intentona Comunista (1935) e o Plano Cohen. Tendo em vista a instabilidade política gerada por tais movimentos, Getúlio Vargas cancela as eleições programadas para 1937 e promulga uma nova Constituição.

A Constituição que vigeu de 1937 até 1946, embora conservasse em seu texto as inovações previstas na Constituição anterior, foi moldada na Constituição Polonesa de 1934 de caráter extremamente autoritário. A intervenção estatal na esfera privada, inclusive no domínio econômico, foi acentuada.

Como exemplo do processo de intervenção iniciado, podemos citar a criação de autarquias econômicas para defesa de produtos da agricultura e da indústria extrativa, o que demandava do Poder Público um conhecimento cada vez mais técnico sobre a área econômica regulada. $\mathrm{O}$ alargamento do Estado também gerou uma máquina administrativa inchada e a criação do Departamento Administrativo do Serviço Público (DASP) que foi o primeiro órgão de gestão do governo.

O período entre 1937 e 1945 foi caracterizado pela regulação de áreas antes não compreendidas no âmbito do controle estatal. Foi nessa época que, com a edição de diversos decretos-leis, surgiram os códigos Penal, de Processo Penal, de Processo Civil e a Lei das Sociedades por Ações, o Código de Minas, a Consolidação das Leis do Trabalho e a Lei de

\footnotetext{
${ }^{9}$ MELLO, Celso Antônio Bandeira de. Curso de Direito Administrativo. 12aed. São Paulo: Malheiros, 2000, p. 558.
} 
Falências, que permaneceram em vigor por muito tempo - e alguns em vigor até hoje com as modificações necessárias para adaptação ao contexto atual.

De 1943 a 1945, o movimento de redemocratização de oposição ao governo autoritário de Getúlio Vargas, começa a surgir mais organizado, tendo como grandes contribuintes Carlos Lacerda, Monteiro Lobato e juristas como José de Magalhães Pinto. Em 1945, apesar de já ter convocado novas eleições para o mesmo ano, Getúlio Vargas é deposto e substituído temporariamente até que Eurico Gaspar Dutra assumisse o poder.

O governo de Gaspar Dutra não adotou nenhuma política eficaz para o fomento da industrialização brasileira. Entretanto, durante o seu governo, uma nova Assembleia Constituinte é convocada e surge o embate entre os defensores do regime centralizador - resquício do Estado Novo - e aqueles que desejavam o retorno do ideal liberal-democrático.

De um modo geral, a Constituição de 1946 em muito se parecia com a promulgada em 1934, tendo ambas as constituintes o interesse de frear o alargamento do poder executivo e o regime autoritário que as precedia. A Constituição de 1946 expressava uma preocupação acentuada com as questões regionais, tendo instituído na própria estrutura da ordem econômica o objetivo de reduzir essas diferenças.

Apenas na segunda era Vargas, iniciada em 1951, o projeto desenvolvimentista, estagnado durante o governo de Gaspar Dutra, foi retomado. Vargas implementou políticas intervencionistas visando o desenvolvimento da indústria nacional. Como já sabemos, essa política intervencionista foi marcada pela criação de empresas públicas, como a Petrobras, Companhia Siderúrgica Nacional e Companhia Vale do Rio Doce, que deveriam prestar os serviços estratégicos e necessários para o 
desenvolvimento brasileiro. Por demandarem alto investimento e retorno em longo prazo, essas atividades foram bancadas inicialmente pelo Estado. Formava-se o embrião do Estado empresário brasileiro, com a atuação direta do estado na economia.

Em 1955, Juscelino Kubitschek assume a presidência da república e mantém o ideal desenvolvimentista com o seu ambicioso Plano de Metas e o lema "50 anos em 5". O plano do então presidente abriu as portas brasileiras para o capital estrangeiro, permitindo a instalação de empresas multinacionais renomadas e acelerando de forma acentuada o crescimento industrial brasileiro.

Jânio Quadros toma posse como presidente em 1961, mas sem expressão ou apoio político, renuncia logo em seguida sem completar sequer um ano de governo. João Goulart assume sob fortes protestos e veto das Forças Armadas.

Em 1964, João Goulart edita três decretos ${ }^{10}$ polêmicos que versavam claramente sobre a intervenção do Estado na atividade privada, decretando a possibilidade de desapropriação de áreas em favor da Petrobrás e próximas a áreas rurais que eram objeto de investimentos da União. As atitudes de João Goulart - intituladas na época de "esquerdistas" - geraram insatisfação nos diversos segmentos da sociedade e culminaram com o golpe militar em março de 1964.

O período entre 1964 e 1985 foi marcado pela edição dos Atos Institucionais que, em muitos casos, desautorizavam ou alteravam direitos concedidos pela Constituição de 1946. Em 1967, foi promulgada uma nova Constituição que não demonstrou grande avanço frente à Constituição de 1946.

${ }^{10}$ Decretos $\mathrm{n}^{\mathrm{os}} .53 .700 / 64,53.701 / 64$ e 53.702/64. 
Formalmente, a Constituição de 1967 previa liberdades e garantias que, na prática, nem sempre eram aplicadas. O texto constitucional dava forte ênfase para a faculdade de o Estado intervir no setor privado em prol da segurança nacional e aderia uma série de princípios presentes nos Atos Institucionais anteriores à ela.

$\mathrm{O}$ regime militar adotou uma política econômica bem rígida na tentativa de estabilizar a inflação. O plano previa o corte de gastos em empresas estatais (para que passassem a ser rentáveis), a adoção de um câmbio realista e a diminuição salarial do setor público. Apesar do elevado custo social, a inflação efetivamente caiu e a abertura econômica para o capital estrangeiro passou a se efetivar. O "milagre econômico" custeado, em grande parte, pelo capital estrangeiro começou a ruir no final da década de 70 com a crise do petróleo.

Durante todo o período da ditadura, para manter o desenvolvimento, assegurar a prestação de serviços e a realização de obras públicas faraônicas o aparelho estatal foi aumentado de tal forma que a carga tributária já não dava mais conta de suprir os gastos do Estado. Desde Vargas e JK, a busca por recursos no mercado internacional foi aumentando o endividamento externo brasileiro, que, com a volta da crescente inflação e o aumento da taxa de juros internacional, tornou a situação econômica do país insustentável, enfraquecendo ainda mais o governo dos militares.

Por isso, em 1980, além do regime político totalitário, a crise econômica inflacionária e a conjuntura fiscal agravada fizeram com que o modelo intervencionista de Estado empresário passasse a sofrer duras críticas. A crise econômica, inclusive, foi um dos fatores catalisadores da redemocratização.

A essa altura, o modelo intervencionista já tinha sido questionado internacionalmente, surgindo um ideal "neoliberal" que pretendia uma 
intervenção "mínima" na economia. Não se pode dizer que a Constituição de 1988 adotou uma posição neoliberal, até porque, considerando o contexto social da época, os objetivos sociais eram muito importantes.

Como veremos mais detalhadamente adiante, a Constituição de 88 adotou com clareza um papel gerencial e regulador para o Estado. Fato é que o constituinte reconheceu que o Estado, até por possuir procedimentos administrativos próprios, não tem o mesmo grau de eficiência do setor privado. Tornou-se evidente que os serviços prestados pelo Estado empresário (modelo adotado até então) poderiam ser mais bem desenvolvidos por particulares (com a supervisão/fiscalização do Estado) e estariam resultando apenas em gastos maiores ao erário.

Diante desse histórico, foi necessário repensar o modelo de intervenção estatal tendo em vista os resultados negativos obtidos com o plano intervencionista/desenvolvimentista. Considerando a falta de recursos financeiros e técnicos para suprir as necessidades da sociedade, o Estado iniciou um processo de transferência de algumas atividades, que até então exercidas exclusivamente por ele, para o setor privado.

Nesse contexto, inicia-se o processo de desestatização brasileiro que tem como primeiro marco regulatório o Decreto n. 91.991 de 28 de novembro de 1985 - editado durante o governo de José Sarney. Em sequência, já no governo de Fernando Collor, houve a promulgação da Lei n. 8.031 de 12 de abril de 1990, conhecida como "Plano Nacional de Desestatização"- PND. O PND foi mais arrojado e flexibilizou ainda mais o ideal nacionalista e de segurança nacional previsto no Decreto n. 91.991/85, possibilitando que mais atividades fossem repassadas à iniciativa privada.

Aqui vale ressaltar a diferença indicada por José dos Santos Carvalho Filho entre desestatização, como o processo que retira o Estado de determinado setor de atividade, e privatização, que denota apenas o 
processo de converter algo em privado. Essa distinção é de suma importância haja vista que os planos não buscavam a privatização das atividades - já que muitas delas continuariam a ser serviços públicos de titularidade estatal - mas apenas a sua execução. ${ }^{11}$

$\mathrm{O}$ ápice deste processo veio durante o governo de Fernando Henrique Cardoso com a implementação do Plano Diretor da Reforma do Aparelho do Estado - PDRAE e a edição da Lei n. 9.491 de 9 de setembro de 1997 e do Decreto n. 2.594 de 15 de maio de 1998, que estabeleciam novas bases e procedimentos para a desestatização.

Segundo Alexandre Ribeiro Sampaio "a formação do Estado regulador no Brasil se cumpriu em contexto interno - político, social e econômico - próprio" ${ }^{\text {"12 }}$. O PDRAE, foi o principal marco para a instauração do modelo de Estado regulador brasileiro. Lançado em 1995, o plano buscava criar condições para reconstrução da administração pública em bases modernas e racionais.

O PDRAE, elaborado por Bresser-Pereira, descrevia a evolução da regulação no Estado brasileiro desde a época do período imperial até os dias atuais. De acordo com a apresentação do plano, o período imperialista brasileiro foi caracterizado por uma administração patrimonialista em que os detentores do poder não viviam mais da renda de suas terras, mas sim pela renda oriunda do Estado.

O processo de desestatização nada mais fez do que abandonar a ideia do Estado como prestador de serviços transferindo para a iniciativa privada a execução de atividades que seriam mais eficientes se realizadas pela iniciativa privada.

\footnotetext{
${ }^{11}$ CARVALHO FILHO. José dos Santos. Op. cit., p. 349

${ }^{12}$ SAMPAIO, Alexandre Ribeiro. Notas essenciais sobre o modelo brasileiro de Estado regulador: Antecedentes históricos e formato adotado. Revista Forense, Rio de Janeiro, n. 414, p. 425, 2011
} 
De antemão cumpre ressaltar que os planos de desestatização, especialmente o PDRAE, buscavam mais do que uma reorganização das atividades do Estado, mas um novo modelo de organização estatal, uma reforma do Estado e do aparelho estatal. Sobre este fenômeno, Alexandre Ribeiro Sampaio citando trechos do PDRAE, assevera que:

"uma reforma do Estado 'é um projeto amplo que diz respeito às várias áreas do governo e, ainda, ao conjunto da sociedade brasileira, enquanto que a reforma do aparelho do Estado tem um escopo mais restrito: está orientada para tornar a administração pública mais eficiente e mais voltada para a cidadania'. Assim, o PDRAE foca, especialmente, a reforma da administração pública federal. Já a reforma do Estado pretende a 'redefinição do papel do Estado, que deixa de ser o responsável direto pelo desenvolvimento econômico e social pela via da produção de bens e serviços, para fortalecer-se na função de promotor e regulador desse desenvolvimento'." 13

Do trecho, podemos perceber que após décadas desenvolvendo diretamente atividades empresariais (de titularidade não exclusiva do Estado) e serviços públicos (de titularidade exclusiva do Estado), o Estado decidiu afastar-se deste posto cedendo à iniciativa privada essa tarefa.

Entretanto, considerando a relevância destas atividades para o funcionamento da economia e, de um modo mais geral, a existência digna dos cidadãos, não bastaria enxugar as contas públicas. Para que o Estado continuasse influindo nesses setores garantindo a universalização e qualidade mínima dos serviços, o controle contra a concentração de poder e o desenvolvimento desses setores, o Estado assumiu o papel regulador.

A solução encontrada também passa pela criação de agências reguladoras e, como veremos mais detalhadamente adiante, alinha-se com as funções delimitadas pela Constituição em seu artigo 174, exercendo um poder regulador, normativo e fiscalizador. É nesse contexto que inicia-se a atuação mais marcante do Estado brasileiro como regulador da ordem econômica.

\footnotetext{
${ }^{13}$ Ibidem, p. 425.
} 


\section{PRINCÍPIOS CONSTITUCIONAIS ECONÔMICOS}

Para que possamos delimitar corretamente os princípios constitucionais econômicos - estabelecidos expressamente no art. 170 da Constituição, é necessário, primeiramente, visualizar a Constituição como um todo, sendo guiada por decisões políticas do constituinte originário que estão consagradas no preâmbulo e no Título I da Carta Magna.

Nesse sentido, vejamos o que estabelece a Constituição Brasileira em seu artigo $1^{\circ}$ como princípios fundamentais do Estado brasileiro:

"Art. $1^{\circ}$ A República Federativa do Brasil, formada pela união indissolúvel dos Estados e Municípios e do Distrito Federal, constitui-se em Estado Democrático de Direito e tem como fundamentos:

I - a soberania;

II - a cidadania

III - a dignidade da pessoa humana;

IV - os valores sociais do trabalho e da livre iniciativa;

V - o pluralismo político." (grifos nossos)

Considerando os valores expressos no artigo $1^{\circ}$ da Constituição, podemos depreender dois conceitos importantes: (a) a interpretação da livre iniciativa, da proteção da dignidade da pessoa humana e do valor social do trabalho como diretrizes maiores a serem seguidas pelo Estado e por toda a sociedade, e (b) a adoção do modelo econômico de bem-estar social. Estas são diretrizes sob as quais a ação do Estado e da iniciativa privada devem estar subordinadas.

Sobre este viés, percebe-se que tais valores superam a questão setorial econômica para alcançar uma maior relevância no atual Estado brasileiro, qual seja a própria formação do Estado Democrático de Direito, uma vez que sem livre iniciativa, valorização do trabalho humano e dignidade da pessoa humana não se garante o Estado Democrático de Direito.

Para garantir o funcionamento do Estado Democrático de Direito e o cumprimento das decisões políticas adotadas pelo constituinte, os princípios 
estabelecidos no artigo $1^{\circ}$ irradiam efeitos em todas as relações. Assim, a interpretação do art. 170, e de qualquer outro dispositivo constitucional ou infraconstitucional só é completa se vistos como parte de um todo que busca a realização e manutenção dos fundamentos básicos instituídos no art. $1^{\circ}$ da Constituição.

Dito isso, passamos a interpretação dos princípios ditos “constitucionais econômicos" elencados no art. 170 da Carta Magna:

"Art. 170. A ordem econômica, fundada na valorização do trabalho humano e na livre iniciativa, tem por fim assegurar a todos existência digna, conforme os ditames da justiça social, observados os seguintes princípios:

I - soberania nacional;

II - propriedade privada;

III - função social da propriedade;

IV - livre concorrência;

$\mathrm{V}$ - defesa do consumidor;

VI - defesa do meio ambiente, inclusive mediante tratamento diferenciado conforme o impacto ambiental dos produtos e serviços e de seus processos de elaboração e prestação;

VII - redução das desigualdades regionais e sociais;

VIII - busca do pleno emprego;

IX - tratamento favorecido para as empresas de pequeno porte constituídas sob as leis brasileiras e que tenham sua sede e administração no País.

Parágrafo único. É assegurado a todos o livre exercício de qualquer atividade econômica, independentemente de autorização de órgãos públicos, salvo nos casos previstos em lei."

Da leitura do dispositivo constitucional citado acima, percebemos não ser por acaso que, ao dispor sobre os princípios gerais da atividade econômica em seu Título VII - Da Ordem Econômica e Financeira, o constituinte voltou a consagrar a livre iniciativa e o valor do trabalho humano como fundamentos desta ordem, uma vez os princípios ali elencados são frutos da simples decomposição destes fundamentos.

Acerca da irradiação do fundamento da livre iniciativa nos princípios econômicos do art. 170, observa Luís Roberto Barroso:

"O princípio da livre iniciativa, por sua vez, pode ser decomposto em alguns elementos que lhe dão conteúdo, todos eles desdobrados no texto constitucional. Pressupõe ele, em primeiro lugar, a existência de propriedade privada, isto é, de apropriação particular dos bens e dos meios de produção $\left(\mathrm{CF}\right.$, arts. $5^{\circ}$, XXII e 170 , II). De parte isto, integra, igualmente, o núcleo da idéia de livre iniciativa a liberdade de empresa, conceito materializado no parágrafo único do art. 170, que 
assegura a todos o livre exercício de qualquer atividade econômica, independentemente de autorização, salvo nos casos previstos em lei. Em terceiro lugar situa-se a livre concorrência, lastro para a faculdade de o empreendedor estabelecer os seus preços, que hão de ser determinados pelo mercado, em ambiente competitivo (CF, art. 170, IV). Por fim, é da essência do regime da livre iniciativa a liberdade de contratar, decorrência lógica do princípio da legalidade, fundamento das demais liberdades, pelo qual ninguém será obrigado a fazer ou deixar de fazer alguma coisa senão em virtude de lei $\left(\mathrm{CF}\right.$, art. $5^{\circ}$, II). ${ }^{, 14}$ ( grifos no original)

Cabe aqui lembrar a lição de Miguel Reale para justificar que o fundamento da livre iniciativa, embora intrinsecamente ligado ao princípio da livre concorrência - já que um sem o outro não sobrevive - com ele não se confunde:

"livre iniciativa e livre concorrência são conceitos complementares, mas essencialmente distintos. A primeira não é senão a projeção da liberdade individual no plano da produção, circulação e distribuição das riquezas, assegurando não apenas a livre escolha das profissões e das atividades econômicas, mas também autônoma eleição dos processos ou meios julgados mais adequados à consecução dos fins visados. (...) Já o conceito de livre concorrência tem caráter instrumental, significando o 'Principio Econômico' segundo o qual a fixação dos preços das mercadorias e serviços não deve resultar de atos cogentes da autoridade administrativa, mas sim do livre jogo das forças em disputa de clientela na economia de mercado." ${ }^{\prime 5}$

Ainda segundo Reale, a consagração dos princípios da livre iniciativa e da livre concorrência como resultado da opção política econômica do nosso constituinte pelo tipo liberal do processo econômico é indiscutível. A aplicação desta política econômica envolve a intervenção do Estado apenas para coibir abusos do poder econômico e preservar a livre concorrência de interferências externas causadas pelo próprio Estado ou por um agente econômico visando à dominação de mercado ou aumento arbitrário de seus lucros.

Por outro lado, ao consagrar princípios de interesse coletivo e sociais, percebemos que o modelo de liberalismo econômico clássico não foi adotado em sua totalidade. A necessidade de equilibrar a livre iniciativa

\footnotetext{
${ }^{14}$ BARROSO, Luís Roberto. A Ordem Econômica Constitucional e os Limites à Atuação Estatal no Controle de Preços. Revista de Direito Administrativo, Rio de Janeiro, v. 226, p.189-190

${ }^{15}$ REALE, Miguel. Plano Collor II e a Intervenção do Estado na Ordem Econômica. Revista de Direito Bancário e do Mercado de Capitais, São Paulo, n. , p.312
} 
e livre concorrência com os demais princípios constantes do art. 170 nos aproximou de um modelo de bem-estar social.

Ao lado da livre iniciativa, a valorização do trabalho humano, segundo fundamento da ordem econômica, está refletida ao longo de todo o texto constitucional, desde o artigo $7^{\circ}$ - que estabelece uma série de direitos dos trabalhadores -, como no próprio inciso VIII do art. 170, que identifica a busca pelo pleno emprego como um princípio orientador da ordem econômica.

Com um olhar um pouco mais atento, veremos que a dignidade $d a$ pessoa humana, por mais que não esteja expressamente estipulada como fundamento da ordem econômica, se desdobra diretamente em três grandes princípios econômicos, quais sejam: (i) defesa do consumidor, (ii) defesa do meio ambiente, e (iii) redução das desigualdades regionais e sociais.

A função social da propriedade perpassa por mais de um fundamento, pois implica não apenas na garantia e na existência da propriedade privada, mas também requer a utilização produtiva da mesma, gerando os benefícios sociais vislumbrados pelo constituinte.

De certa forma, conceituados de forma isolada, os princípios parecem conflitantes e, por isso, torna-se tão importante a classificação feita por Luís Roberto Barroso acerca dos princípios da ordem econômica. Segundo ele, o art.170 elenca princípios de funcionamento e princípios-fins da ordem econômica. Os primeiros devem servir de parâmetro de convivência para os agentes da ordem econômica, enquanto os últimos descrevem realidades materiais que o constituinte desejaria que fossem alcançadas. ${ }^{16}$

Os princípios mencionados nos incisos I a VI (soberania nacional, propriedade privada, função social da propriedade, livre concorrência,

\footnotetext{
${ }^{16}$ BARROSO, Luís Roberto. Op. cit. p. 193 et. seq.
} 
defesa do consumidor e defesa do meio ambiente) do art. 170 seriam, na classificação de Luís Roberto Barroso, princípios de funcionamento. Eles regem as relações produtivas entre os agentes econômicos.

A aplicação destes princípios na ordem econômica pode ser percebida, por exemplo, quando há reserva de mercado em setor estratégico (soberania nacional), desapropriação de um imóvel pela inutilização ou utilização inadequada da propriedade (função social da propriedade), o condicionamento de uma determinada operação ao cumprimento de restrições anticoncorrenciais sobre o mercado (livre concorrência e defesa do consumidor) e também na imposição de restrições ao exercício de determinadas atividades industriais em áreas de preservação ambiental tendo em vista um desenvolvimento sustentável (defesa do meio ambiente).

Os princípios-fins, de maneira geral, são os objetivos que devem ser almejados pelo Estado quando ele intervém na ordem econômica, seja para induzir a iniciativa privada ou como agente econômico direto. Os incisos VII, VIII e IX, e o parágrafo único do art. 170 retratam essas finalidades e devem servir de base para a implementação de políticas econômicas de governo.

Fato é que, utilizando-se dos princípios de funcionamento, quer o constituinte que alcancemos os princípios-fins, restando clara a ideia de que a atividade econômica deve funcionar como um dos instrumentos para garantir a justiça social - valor base dos princípios-fins.

Os princípios gerais da atividade econômica devem, portanto, assegurar a todos a existência digna, de acordo com os ditames da justiça social. Dessa forma, não há dúvidas de que a intervenção no domínio da autonomia privada se justifica apenas para garantir o objetivo ao qual se destina - "função social da atividade econômica". 
Assim como ocorre com todos os outros princípios constitucionais, por mais que aparentemente conflitantes, a livre iniciativa e a livre concorrência, e os demais princípios econômicos, devem ser harmonizados de maneira que possam conviver dentro da mesma ordem jurídica.

Em outras palavras, nenhum princípio é absoluto e, o eventual choque entre eles, deve ser solucionado através da ponderação dos mesmos, levando em consideração o conteúdo típico de cada princípio. Essa ponderação deve ser feita em bases proporcionais e razoáveis sem que o resultado final implique em anulação de qualquer princípio.

O fato da aplicação radical e extrema dos princípios gerar conflito entre eles não autoriza a transgressão de um determinado princípio em benefício ou como garantia de outro. Não está o Estado, sob o pretexto de garantia dos interesses coletivos tutelados no art. 170, autorizado a livremente intervir na ordem econômica, inviabilizando, ou mesmo anulando, a livre iniciativa. Por isso, a própria Constituição em seu artigo 173 estabelece que a intervenção estatal se dará em caráter excepcional.

É nesse sentido o entendimento Supremo Tribunal Federal, como se percebe do trecho abaixo:

"Em face da atual Constituição, para conciliar o fundamento da livre iniciativa e do princípio da livre concorrência com os da defesa do consumidor e da redução das desigualdades sociais, em conformidade com os ditames da justiça social, pode o Estado, por via legislativa, regular a política de preços de bens e de serviços, abusivo que é o poder econômico que visa ao aumento arbitrário dos lucros." ${ }^{17}$

É certo que, se levarmos os conceitos ao extremo, o sistema da economia de mercado, em que cada indivíduo busca a maximização de seus ganhos, parecerá sempre em contraposição ao dispositivo legal que confere ao Estado a tarefa de coibir o abuso econômico que vise o aumento arbitrário dos lucros (art. 173, $\S 4^{\circ}, \mathrm{CF}$ ). Por isso, como bem salienta Pedro

\footnotetext{
${ }^{17}$ STF, ADI n. 319/QO, Rel. Min. Moreira Alves, Brasília, 3 mar.1993.
} 
Paulo Salles Cristofaro ${ }^{18}$, torna-se extremamente necessário "harmonizar tais normas, de sorte a que não sejam reprimidas condutas que são inerentes ao próprio sistema econômico".

Assim, observadas essas finalidades sociais, as atividades econômicas serão regidas pelo regime de livre iniciativa, sendo proibida ao Estado a execução dessas atividades - salvo as hipóteses previstas constitucionalmente, e devendo o Estado, apenas em caráter excepcional, intervir na seara privada.

Sobre o limite da intervenção estatal, Celso Antônio Bandeira de Mello ainda dispõe:

"Em todos os casos, necessariamente, a interferência estatal terá que estar volvida a satisfação dos fins dantes aludidos como sendo os caracterizadores do Estado brasileiro; e jamais - sob pena de nulidade - poderá expressar tendência ou diretriz antinômica ou gravosa àqueles valores."

Acerca da limitação constitucional à intervenção estatal, cabe ressaltar que o próprio parágrafo único ${ }^{20}$ do art. 170 aduz ao entendimento de que a livre iniciativa sem a necessidade de qualquer autorização governamental deve ser a regra, excepcionando-se apenas os casos em que a lei estabelecer as autorizações especiais a que deve o particular se sujeitar. A redação do referido parágrafo não confere à lei o poder de excepcionar o exercício da livre iniciativa, privando a iniciativa privada de determinada atividade econômica, mas apenas de estabelecer autorizações prévias do Poder Público para exercê-las.

Da mesma forma, não pode a autorização imposta versar sobre os aspectos econômicos da atividade empreendida pelo particular, mas apenas

\footnotetext{
${ }^{18}$ CRISTOFARO, Pedro Paulo Salles. Comentários ao art. 36, inciso III da Lei 12.529/2012. (artigo ainda não publicado)

${ }^{19}$ MELLO, Celso Antônio Bandeira de. Curso de Direito Administrativo. 28. ed. São Paulo: Malheiros, 2011. p.769.

${ }^{20} \mathrm{CF}$, Art. 170. (...) Parágrafo único. É assegurado a todos o livre exercício de qualquer atividade econômica, independentemente de autorização de órgãos públicos, salvo nos casos previstos em lei.
} 
instituir controles mínimos de segurança, meio ambiente, salubridade e outros aspectos que, respeitando os princípios constitucionais econômicos, dizem respeito apenas ao mínimo desejável de determinado produto ou negócio.

Conclui-se, portanto, que o fato do legislador constitucional ter determinado como princípios da atividade econômica a defesa do consumidor, a livre concorrência, a defesa do meio ambiente e, principalmente, a redução das desigualdades sociais, só reforçam a ideia de que a livre iniciativa da atividade econômica cumpre a sua função social quando serve de instrumento para garantir uma existência digna para os cidadãos, mas não é ela (a iniciativa privada) obrigada a fazê-lo, este dever é do Estado.

Por ora, para que possamos adentrar no estudo concreto da atuação e dos limites de intervenção do Estado no domínio econômico, é necessário ter em mente (i) que todos os princípios setoriais da ordem econômica devem ser harmonizados, e (ii) que a economia de mercado - que tem como pilares a livre iniciativa e a livre concorrência - foi o sistema econômico adotado pelo constituinte para alcançar os fins sociais e econômicos por ele desejados. 


\section{FORMAS DE ATUAÇÃO DO ESTADO NA ECONOMIA}

Primeiramente, para que possamos entender o processo de intervenção estatal faz-se necessário distinguir a atuação estatal da intervenção. Via de regra, os vocábulos "atuação" e "intervenção" são utilizados de forma equivalente, como se fossem intercambiáveis. De certo modo, quando utilizamos "atuação" em referência a uma atividade interventiva do Estado, esta substituição se justifica, pois a intervenção é uma espécie de atuação do Estado. O que ocorre é apenas a substituição do gênero pela espécie.

Por outro lado, quando empregamos o vocábulo "intervenção" para configurar uma atuação positiva do Estado, essa substituição pode não ser tecnicamente correta já que nem toda atuação estatal é, necessariamente, uma intervenção. Por que essa diferença? A atuação envolve qualquer atividade positiva de alguém, enquanto o conceito de intervenção demanda que essa atuação seja direcionada para uma área em que o agente não é o titular, ou seja, ele atua em área de outrem.

É certo que toda intervenção demanda, necessariamente, uma atuação do Estado no sentido de intervir em um âmbito que não lhe é próprio. De outra sorte, a atuação estatal, por si só, não pode ser compreendida como sinônimo de intervenção, visto que o Estado pode atuar em setores em que ele mesmo é o titular. Sobre essa distinção Eros Grau anota:

\footnotetext{
"Aludimos, então, à atuação do Estado além da esfera do público, ou seja, na esfera do privado (área de titularidade do setor privado). A intervenção, pois, na medida em que o vocábulo expressa, na sua conotação mais vigorosa, precisamente atuação na área de outrem. (...) Por isso que o vocábulo e expressão não são absolutamente, mas apenas relativamente, intercambiáveis. Intervenção indica, e sentido forte (isto é na sua conotação mais vigorosa), no caso, atuação estatal em área de titularidade do setor privado; atuação estatal, simplesmente, ação do Estado tanto na área de titularidade própria quanto em área de titularidade do setor privado. Em outros termos, teremos que intervenção conota atuação estatal no campo da atividade econômica em sentido estrito;
} 
atuação estatal, ação do Estado no campo da atividade econômica em sentido amplo."${ }^{21}$

Como se vê, não há que se falar em intervenção do Estado em campo de atuação que a titularidade a ele pertence. Se há, então, um campo de titularidade próprio do Estado, para que exista intervenção deve, necessariamente, existir um campo em que ele, Estado, não é titular, mas sim o setor privado.

Utilizando-se dessa diferenciação, Caros Alberto de Moraes Ramos Filho, bem define a intervenção do Estado no domínio econômico como:

“o conjunto de atividades estatais sobre o segmento econômico, que é próprio da iniciativa privada, visando os fins traçados pela Constituição e utilizando-se, legitima e razoavelmente, dos instrumentos e mecanismos postos à disposição estatal pelo Texto Constitucional".

A própria definição de intervenção nos remete a separação dos campos de atuação do Estado e dos particulares. Sobre essa distinção, Celso Antônio Bandeira de Mello observa que:

"a Constituição estabeleceu uma grande divisão: de um lado, as atividades que são das alçadas dos particulares - as econômicas; e, de outro, atividades que são da alçada do Estado, logo, implicitamente qualificadas como juridicamente não econômicas - os serviços públicos". ${ }^{22}$

Assim, na divisão pensada por Celso Antônio Bandeira de Mello, apesar de gerarem proveitos econômicos, os serviços públicos devem ser reconhecidos como não econômicos apenas para fins exclusivamente jurídicos, o que significa dizer que ele não é uma atividade econômica inserida no regime da livre iniciativa. ${ }^{23}$

\footnotetext{
${ }^{21}$ GRAU, Eros Roberto. A Ordem Econômica na Constituição de 1988. 15a. ed. São Paulo: Malheiros,2012. p. 90-91.

${ }^{22}$ BANDEIRA DE MELLO. Celso Antônio. Op. cit. p. 768

${ }^{23}$ Sobre a possibilidade de serviços públicos terem caráter econômico, Celso Antônio Bandeira de Mello assevera: "À vista destas disposições constitucionais, bem se vê o quanto é absurdo disparatado, mesmo - falar em "serviço público econômico", pois se estaria a associar duas expressões que, em nosso Direito Constitucional, designam antinomias jurídicas, necessariamente submetidas, então a regime normativos antagônicos"
} 
De certa forma, a posição adotada por Bandeira de Mello se contrapõe ao entendimento de Eros Grau que entende “inexistir, em um primeiro momento, oposição entre atividade econômica e serviço público" ${ }^{24}$. Entendo que a classificação de Eros Grau é interessante até para que fique claro que os serviços públicos também estão inseridos na ordem econômica e devem seguir seus princípios.

Acerca da diferenciação entre atividade econômica como gênero e espécie e a inserção dos serviços públicos nesse sistema, Eros Grau observa que:

\begin{abstract}
"A prestação de serviço público está voltada à satisfação de necessidades, o que envolve a utilização de bens e serviços, recursos escassos. Daí podemos afirmar que o serviço público é um tipo de atividade econômica.
\end{abstract}

Serviço público - dir-se-á mais - é o tipo de atividade econômica cujo desenvolvimento compete preferencialmente ao setor público. Não exclusivamente, note-se, visto que o setor privado presta serviço público em regime de concessão ou permissão." 25

Tendo essas premissas em mente, o autor classifica os serviços públicos como um tipo de atividade econômica, tornando-a um gênero do qual o serviço público é espécie. Cabe ressaltar que dentro do gênero atividade econômica (ao qual ele se refere como "atividade econômica em sentido amplo") também existe a espécie "atividade econômica" da qual o setor privado é o titular e que é chamada por Eros Grau de "atividade econômica em sentido estrito". Apenas para fins didáticos, essa será a nomenclatura utilizada no presente trabalho.

Após separarmos o campo das atividades do Estado e dos particulares, temos que, por força do princípio da legalidade, as atividades estatais se restringem àquelas expressamente autorizadas pela Constituição, sendo vedado o desenvolvimento de quaisquer outras. As atividades estatais previstas na Constituição podem se subdividir em: (i) serviços públicos

\footnotetext{
${ }^{24}$ GRAU, Eros Roberto. Op. cit. p. 99

${ }^{25}$, Ibid. p. 99.
} 
(privativos e não privativos ${ }^{26}$ ), (ii) atividades econômicas em regime de monopólio estatal (previstas no art. 177, CF) e (iii) atividades econômicas em sentido estrito realizadas em caráter excepcional.

No campo privado, a contrario sensu, as atividades permitidas aos particulares são todas aquelas não proibidas por lei, compreendendo: (i) as atividades econômicas em sentido estrito; e (ii) os serviços públicos não privativos do Estado. Portanto, considerando as excludentes previstas constitucionalmente, só estão fora do escopo das atividades privadas o monopólio estatal e os serviços públicos privativos, que ainda assim podem ser desenvolvidos pelo particular em regime de concessão ou permissão.

A separação entre privado e público é de relevante importância, pois que sem delimitarmos o escopo de atuação do Estado, nunca conseguiremos definir quando ele está, de fato, intervindo e quando está simplesmente atuando. Como o escopo do presente trabalho se restringe à atuação do Estado como interventor, os campos em que ele atua como titular da atividade serão, por ora, deixados de lado.

Dito isso, passemos a explanação dos papéis que o Estado assume na ordem econômica da Constituição de 1988, quais sejam: Estado Executor e Estado Regulador.

\subsection{ESTADO EXECUTOR}

O Estado Executor será aquele que intervém no domínio econômico. Ele assumirá o papel de um agente econômico no campo das atividades econômicas em sentido estrito - isto é, executará atividades que são primordialmente de titularidade do setor privado.

Como regra geral, o Estado exerce a exploração direta dessas atividades econômicas em conformidade com o art. 173 da Constituição:

\footnotetext{
${ }^{26}$ GRAU, Eros Roberto. Ibid, p. 120.
} 
"Art. 173. Ressalvados os casos previstos nesta Constituição, a exploração direta de atividade econômica pelo Estado só será permitida quando necessária aos imperativos da segurança nacional ou a relevante interesse coletivo, conforme definidos em lei."

Como se vê, o constituinte estabeleceu diversos limites à atuação do Estado no campo das atividades econômicas em sentido estrito para preservar a liberdade de iniciativa dos particulares, uma vez que a titularidade desse campo a eles pertence.

Em sua seção principal, quer o constituinte estabelecer que essa intervenção ocorra apenas em caráter excepcional. A regra é o Estado não atuar no campo privado, mas poderá assim proceder, excepcionalmente, quando necessária para garantir a "segurança nacional" ou "relevante interesse coletivo".

O constituinte mais uma vez se utilizou de termos abertos para garantir a atemporalidade da norma constitucional. Os imperativos de segurança nacional e interesse coletivo são conceitos jurídicos indeterminados que deveriam ser preenchidos por lei. Embora essa lei ainda não tenha sido editada, a limitação já está vigente, pois não depende da lei para ter eficácia.

Outro ponto é que a lei a que o art. 173 da Constituição se refere deve ser (i) lei federal, quando tratar de segurança nacional, uma vez que a competência para legislar sobre esse assunto é privativa da União ${ }^{27}$; e (ii) pode ser lei federal ou estadual, conforme o caso, quando se tratar de interesse coletivo, já que a competência para legislar sobre direito econômico é concorrente da União e dos Estados-membros ${ }^{28}$, sendo nessa última hipótese justificado o relevante interesse coletivo predominantemente estadual.

\footnotetext{
${ }^{27} \mathrm{CF}$, art. 22, XXVIII.

${ }^{28} \mathrm{CF}$, art. 24, I.
} 
Alguns outros pontos relevantes devem ser levantados sobre a redação do art. 173 da Constituição, antes que adentremos nas modalidades de intervenção do Estado Executor. A redação do referido artigo além de limitar as hipóteses de cabimento dessa intervenção no domínio econômico, excetua os demais casos previstos na Constituição.

De pronto, nos questionamos quais seriam esses casos? Certamente o constituinte quis se referir ao monopólio estatal, expressamente previsto no art. 177 e no art. 21, inciso XXIII da Constituição. Mais uma vez recorreremos aos ensinamentos de Eros Grau sobre o assunto:

\begin{abstract}
"A atuação do Estado no campo da atividade econômica em sentido estrito, como agente econômico, é prevista, pelo texto constitucional, no seu art. 177. Cuida-se, aí, de atuação em regime de monopólio. Apenas esse caso justificaria, já, a menção inicial, contida no preceito veiculado pelo art. 173 do texto constitucional. Além dele, contudo, outro mais encontramos precisamente no referido inciso XXIII do art. 21. (...) No caso, assim como naquele do art. 177 monopólio do petróleo e gás natural -, razões creditadas aos imperativos de segurança nacional é que justificam a previsão constitucional de atuação do Estado, como agente econômico, no campo da atividade econômica em sentido estrito. Não há, pois, aí, serviço público."29
\end{abstract}

Daí, como se vê, ser tão importante a identificação do que é serviço público. As ressalvas previstas no art. 173 não se referem à prestação de serviços públicos, pois esses são espécie da atividade econômica em sentido amplo, e não se confundem com a intervenção do estado na atividade econômica em sentido estrito.

Para que fique ainda mais claro, nos dizeres de Hely Lopes Meirelles e Eros Grau, serviço público é:

(i) "todo aquele prestado pela Administração ou por seus delegados, sob normas e controles estatais, para satisfazer necessidades essenciais ou secundárias da coletividade, ou simples conveniências do Estado." ${ }^{30}$

(ii) "atividade indispensável à consecução da coesão social. Mais: o que determina a caracterização de determinada parcela da atividade econômica em sentido amplo como serviço público é a sua vinculação ao interesse social." ${ }^{\prime 1}$

\footnotetext{
${ }^{29}$ GRAU, Eros Roberto. Ibid, p. 124.

${ }^{30}$ MEIRELLES, Hely Lopes. Direito Administrativo Brasileiro. $38^{\mathrm{a}}$ ed. São Paulo: Malheiros, 2012. p. 289.
} 
Até das definições de serviço público temos que são atividades voltadas para as necessidades da coletividade, dito em sentido maior são atividades que fornecem as necessidades básicas dos cidadãos. Não há prestação de serviço público na exploração de pesquisa, larva, enriquecimento ou industrialização de minérios nucleares, mas apenas uma forte proteção à segurança nacional e o interesse coletivo de que esses bens economicamente estratégicos sejam de titularidade do Estado.

Investido nesse papel executor, o Estado explora a atividade econômica em sentido estrito através de órgãos internos ou de pessoas jurídicas criadas especialmente para a execução destas atividades comerciais (empresas públicas e sociedades de economia mista).

A Emenda Constitucional 19/98 alterou a redação do $\S 1^{\circ}$ do art. $173^{32}$ passando a autorizar a intervenção no domínio econômico através de entidades paraestatais. Em respeito ao art. 37, inciso XIX, a criação dessas entidades só pode ser autorizada por lei específica que deverá elencar as funções para as quais a entidade se destina ${ }^{33}$

Outro aspecto interessante das entidades paraestatais que desenvolvem atividades econômicas em sentido estrito é que, por força do inciso II, do $\S 1^{\circ}$ do art. 173, elas devem se sujeitar ao mesmo regime jurídico das empresas privadas, inclusive quanto às obrigações civis, comerciais, trabalhistas e tributárias. Como bem observa José dos Santos Carvalho Filho, a interpretação da regra deve ser cuidadosa:

"Na verdade, por mais que se aproximem das empresas da iniciativa privada e que sofram a incidência do regime jurídico destas, o certo é que não podem descartar o influxo de algumas regras de direito público, indispensáveis no caso

\footnotetext{
${ }^{31}$ GRAU, Eros Roberto. Op. Cit., p. 126.

${ }^{32} \mathrm{CF}$, Art. 173. (...)§ $1^{\circ}$ A lei estabelecerá o estatuto jurídico da empresa pública, da sociedade de economia mista e de suas subsidiárias que explorem atividade econômica de produção ou comercialização de bens ou de prestação de serviços, dispondo sobre: (...).

${ }^{33} \mathrm{CF}$, Art. 37. "XIX - somente por lei específica poderá ser criada autarquia e autorizada a instituição de empresa pública, de sociedade de economia mista e de fundação, cabendo à lei complementar, neste último caso, definir as áreas de sua atuação;”.
} 
de que se trata, ou seja, de pessoas administrativas vinculadas necessariamente a uma pessoa federativa., 34

É também no mesmo sentido o entendimento de Celso Antônio Bandeira de Mello quando observa haver exagero na redação do $\S 1^{\circ}$ do art. 173. Para ele, o inciso III do mesmo dispositivo - que estabelece a contratação e licitação de serviços e obras de acordo com os princípios da administração pública - representa o fato de que as entidades paraestatais não podem estar inteiramente sob o regime de direito privado, pois sofrem diretamente interferência de regras de direito público administrativo. ${ }^{35}$ Podemos, entretanto, considerar que dentro do possível esses dispositivos serão harmonizados de forma que as empresas públicas e sociedades de economia mista sejam regidas por um regime híbrido.

$\mathrm{O}$ art. 173 ainda estabelece em seu $\S 2^{\circ}$ que "As empresas públicas e as sociedades de economia mista não poderão gozar de privilégios fiscais não extensivos às do setor privado" ${ }^{36}$. Note-se que, ao inverso do que ocorre com o $\S 1^{\circ}$, esse dispositivo não sofre restrições e funciona em sua plenitude vedando qualquer tratamento tributário desigual em favor das entidades paraestatais.

De toda sorte, com todas as ressalvas feitas, o intuito dos referidos dispositivos é claramente o de não conferir tratamento especial às entidades paraestatais que intervém no domínio econômico, uma vez que o tratamento diferenciado geraria concorrência desleal no mercado em que atuam.

Sobre esse assunto, vejamos os comentários do Supremo Tribunal Federal acerca dos dispositivos estudados:

"Quer dizer, o artigo 173 da CF está cuidando da hipótese em que o Estado esteja na condição de agente empresarial, isto é, esteja explorando, diretamente, atividade econômica em concorrência com a iniciativa privada. Os parágrafos, então, do citado art. 173, aplicam-se com observância do comando constante do

\footnotetext{
${ }^{34}$ CARVALHO FILHO. José dos Santos. Op. cit. p. 1012.

${ }^{35}$ BANDEIRA DE MELLO, Celso Antônio. Op. cit. p. 784.

${ }^{36} \mathrm{CF}$, Art. 173. $\$ 2$.
} 
caput. Se não houver concorrência - existindo monopólio, CF, art. 177 - não haverá aplicação do disposto no $\S 1^{\circ}$ do mencionado art. 173.,"37

Feitos os comentários gerais sobre a intervenção do Estado no domínio econômico, passaremos ao segundo papel do Estado conferido pelo art. 174 da Constituição, qual seja, o Estado Regulador.

\subsection{ESTADO REGULADOR}

Antes de adentrarmos nas especificidades do Estado Regulador, cumpre relembrar que esse modelo surge no momento em que o Estado devolve à iniciativa privada uma carga de atividades que havia abarcado durante o período em que atuou como Estado de Bem-Estar. Este retorno não pode significar, entretanto, a volta dos ideais puramente liberalistas e, nesse sentido, o Estado Regulador surge como uma solução de meio termo através da qual ele disciplina os limites da autonomia privada e submete ao seu controle as atividades econômicas relevantes, garantindo a satisfação das necessidades coletivas.

De fato, a iniciativa privada ganhou quantitativamente mais espaço para atuar, sendo permitido a ela, também desenvolver suas atividades em áreas antes reservadas exclusivamente ao domínio estatal. De todo modo, não podemos afirmar que houve um aumento da livre iniciativa, ao menos não do ponto de vista qualitativo, pois a autonomia dos particulares também sofreu restrições consideráveis.

Para que tenhamos uma visão mais completa, vejamos a definição de Estado Regulador, segundo Marçal Justen Filho e José dos Santos Carvalho Filho:

(i) "a existência de um Estado Regulador se caracteriza pela eleição da intervenção regulatória como instrumento político fundamental. Toda atuação estatal - em qualquer modelo de Estado - é vinculada à realização dos princípios e valores fundamentais, especialmente a dignidade da pessoa humana. O modo de realizar tal fim, num Estado Regulador, consiste na atuação regulatória, o que se

\footnotetext{
${ }^{37}$ STE, RE 407.099/RS, Rel. Min. Carlos Velloso, Brasília, 22 jun. 2004.
} 
traduz basicamente na edição de regras e outras providências orientadas a influir sobre a atuação das pessoas e instituições." 38

(ii) "Estado Regulador é aquele que, através de regime interventivo, se incumbe de estabelecer as regras disciplinadoras da ordem econômica com o objetivo de ajustá-la aos ditames da justiça social." ${ }^{39}$

Ambas as definições deixam claro que (i) quando o Estado age em sua função reguladora, o faz sempre intervindo, isso porque regula sempre a atividade econômica em sentido amplo, regulando tanto a atividade econômica em sentido estrito - em que atuam o setor privado e, excepcionalmente o Estado - e os serviços públicos privativos e não privativos - sendo presente a atuação da iniciativa privada em ambos (sendo que no primeiro caso por delegação); e (ii) as normas reguladoras devem servir para guiar a atuação da ordem econômica de modo a conduzi-la à justiça social.

Como bem salienta Marçal Justen Filho o "objetivo da regulação é conjugar as vantagens provenientes da capacidade empresarial com a realização de valores e princípios fundamentais". Nessa linha, temos que a aplicação dos princípios econômicos constitucionais sobre essa intervenção do Estado torna-se ainda mais imperiosa.

Segundo os ensinamentos de Eros Grau, o papel do Estado Regulador seria o de intervir sobre o domínio econômico ${ }^{40}$, abrangendo a regulação da atividade econômica em sentido amplo, utilizando-se para tanto de normas. A aplicação das normas deveria ser fiscalizada para garantir sua concretude e assim conseguiríamos atingir os fins planejados pelo Estado.

A ideia de Eros Grau está pautada no modelo de Estado Regulador brasileiro previsto no art. 174 da Constituição, que é o fundamento legal da atuação reguladora:

\footnotetext{
38 JUSTEN FILHO, Marçal. Op. cit. p.43.

${ }^{39}$ CARVALHO FILHO. José dos Santos. Op. cit. p. 992.

${ }^{40}$ GRAU, Eros Roberto. Op. cit. p.143.
} 
"Art. 174. Como agente normativo e regulador da atividade econômica, o Estado exercerá, na forma da lei, as funções de fiscalização, incentivo e planejamento, sendo este determinante para o setor público e indicativo para o setor privado.

$\S 1^{\circ}$ - A lei estabelecerá as diretrizes e bases do planejamento do desenvolvimento nacional equilibrado, o qual incorporará e compatibilizará os planos nacionais e regionais de desenvolvimento."

Primeiramente, temos que o agente ativo (normativo e regulador) será o Estado, representado, neste caso, por União, Estados Federados e Municípios, que, conforme o interesse predominantemente federal, estadual ou local, atuarão de forma exclusiva ou concorrente, como prevê a distribuição de competências constitucional ${ }^{41}$.

O mandamento constitucional é autoexplicativo, quase redundante, quando caracteriza o Estado como agente normativo e regulador, com funções de fiscalização. Isso porque a regulação em qualquer âmbito implica a edição de normas - já que estas determinam padrões de conduta e garantem coercitividade - e, para assegurar a eficácia e efetividade dessa conduta no plano real, a norma reclama por fiscalização.

Ademais, requer a Constituição que o Estado desenvolva as funções de fiscalização, incentivo e planejamento, "na forma da lei", em respeito ao princípio da legalidade, o que significa que estes terão de ser disciplinados antes de aplicados. O que parece ser a intenção do constituinte nessa passagem é a de impor ao Estado atos vinculados. Trata-se da aplicação concreta de normas que são criadas pelo próprio Estado e, por isso, deve-se ter muito cuidado na aplicação justa e legal desses normativos.

A função de fiscalização é mera resultante do poder de regular. Nos dizeres de José Afonso da Silva:

“A fiscalização, como toda fiscalização, pressupõe o poder de regulamentação, pois ela visa precisamente controlar o cumprimento das determinações daquele e,

\footnotetext{
${ }^{41} \mathrm{CF}$, arts. 22, incisos VII e VIII, 24, inciso I. e 30, incisos I e II.
} 
em sendo o caso, apurar responsabilidades e aplicar penalidades cabíveis. Não fora assim, o poder de fiscalização não teria objeto." ${ }^{42}$

Sobre a função de incentivo, que muitos autores como Luís Roberto Barroso e Celso Antônio Bandeira de Mello associam-na a outra modalidade de intervenção do Estado chamando-a de "fomento", o Estado apoia a iniciativa privada dirigindo os estímulos de acordo com os comportamentos que mais são favoráveis para os planos econômicos estatais. Segundo Barroso:

"Esta é a modalidade própria de que se utiliza o Estado para atingir os princípiosfins da ordem econômica". (...) A peculiaridade dessa forma de intervenção estatal é que ela opera por meio de normas diretivas. A adesão ao comportamento sugerido constitui mera opção dos agentes econômicos que se beneficiariam com os mecanismos de fomento criados em lei." ${ }^{, 43}$

O planejamento a que se refere o art. 173 da Constituição (caput e $\S$ $1^{\circ}$ ) não é o planejamento econômico (leia-se, não está incluído dentro desse conceito os planos econômicos, como , por exemplo, o "Plano Real" ou "Plano Verão"), mas sim o de desenvolvimento nacional. O planejamento do art. 173 quer se referir aos planos que deverão ser elaborados e executados pela União ( $\mathrm{CF}$, art. 21, IX) e aprovados pelo Congresso Nacional (CF, art. 48, IV).

Vale ressaltar também que, em que pese o entendimento de GRAU em sentido contrário ${ }^{44}$, apesar de o dispositivo tornar a adesão da iniciativa privada ao planejamento facultativa, a meu ver, o planejamento continua sendo uma forma de intervenção no domínio econômico, uma vez que aqueles que aderirem ao planejamento, via de regra, estarão em situações mais vantajosas do que os que não aderiram e esse reflexo do mercado se dará como resultado da atividade do Estado.

\footnotetext{
${ }^{42}$ SILVA, José Afonso da. Curso de Direito Constitucional Positivo. $34^{\mathrm{a}}$ ed. São Paulo: Malheiros, 2011, p. 810.

${ }^{43}$ BARROSO, Luís Roberto. Op. cit. p.203

44 Acerca da classificação do planejamento como forma de intervenção no domínio econômico, Eros Grau observa que "O planejamento (...) não consigura modalidade de intervenção, mas simplesmente um método mercê de cuja adoção ela se torna sistematizadamente racional."
} 
Diante do exposto, fica claro o entendimento da doutrina no sentido de que o papel do Estado Regulador está intrinsecamente vinculado à atuação intervencionista para garantia do interesse público. Assim, o Estado deixa de fornecer diretamente serviços ao cidadão (Estado Executor), mas mantêm sua responsabilidade sobre eles para com a sociedade e, por isso, intervém sobre a economia como agente regulador e normativo, tendo funções fiscalizadoras, incentivadoras e planejadoras.

Em suma, o Estado regula a ordem econômica através da edição de normas específicas para cada setor, atuando de três formas:

(a) fiscalização: verificação da conduta dos particulares visando evitar o comportamento abusivo que poderiam causar danos a setores menos favorecidos tais como consumidores e pequenas empresas;

(b) incentivo: estímulo para o desenvolvimento e o investimento em determinado setor econômico, tais como benefícios ou isenções fiscais, a sobretaxação de mercadorias importadas e/ou concessão de financiamentos subsidiados por fundos governamentais, sendo aplicados de acordo com o planejamento econômico adotado pelo governo; e

(c) planejamento: estabelecimento de metas e objetivos gerais para a economia que devem ser norteadores para a concessão de incentivos e a edição de sanções.

No Brasil, com os novos programas de desestatização na década de 90, muitas agências reguladoras foram criadas, tais como a ANATEL (telecomunicações), ANEEL (energia elétrica) e ANP (petróleo). Segundo Sundfeld, a necessidade de autoridades especializadas em assuntos econômicos complexos, criados pela sociedade moderna, é uma das causas da crescente regulação e, inclusive, da criação de agências reguladoras. Ao mesmo tempo, a sociedade precisa de imparcialidade para mediação de conflitos entre particulares, portanto, o juiz comum, apesar de ser imparcial, 
não estaria preparado para enfrentar situações de natureza específica de alguns setores econômicos. ${ }^{45}$

As agências reguladoras independentes, baseadas nas diretrizes gerais fixadas em lei, exercem grande variedade de poderes: (i) normativos, propriamente ditos ou de natureza concreta; (ii) de solução de conflitos de interesses; (iii) investigativos; (iv) fomentadores; e (v) de fiscalização, preventiva ou repressiva.

O traço fundamental das agências reguladoras é o fato de possuírem uma combinação das funções de legislador, promotor e juiz. Os poderes que são conferidos a estes órgãos são relacionados com a físcalização das atividades desenvolvidas pelos particulares, cumprimento das regras estabelecidas nos contratos de concessão, nas licenças ou autorizações, incluindo o estabelecimento de eventuais tarifas, poderes disciplinares, sancionatórios e preventivos de condutas prejudiciais aos interesses tutelados. E, por isso, as Agência Reguladoras serão um dos principais instrumentos do Estado Regulador.

Como veremos no próximo capítulo, embora aparentemente a regulação seja uma modalidade mais branda de intervenção, caso seja utilizada com destemperança na ponderação de princípios constitucionais econômicos pode revelar-se mais danosa do que a intervenção direta, podendo gerar até a inviabilidade da atividade econômica desenvolvida pelo particular.

\footnotetext{
${ }^{45}$ SUNDFELD, Carlos Ari. Op. cit. p. 28-31.
} 


\section{CLASSIFICAÇÃO DAS MODALIDADES INTERVENTIVAS}

As modalidades de intervenção do Estado no domínio econômico se dividem de acordo com a função por ele exercida. Em regra, o Estado Executor atuará diretamente na economia, intervindo no domínio econômico ("Intervenção Direta”), e o Estado Regulador atuará indiretamente, intervindo sobre o domínio econômico ("Intervenção Indireta").

Os autores, via de regra, adotam classificações e nomenclaturas diferentes, mas a essência das classificações seguirá sempre essa mesma estrutura: intervenção direta $x$ intervenção indireta.

\subsection{INTERVENÇÃO DIRETA}

A intervenção direta, para os fins desse trabalho, será aquela feita pelo Estado Executor, quando ele diretamente atua no campo das atividades econômicas em sentido estrito como agente econômico.

Para José Afonso da Silva há duas formas de exploração direta da atividade econômica pelo Estado: (i) o monopólio (art. 177) e (ii) a necessária - exploração estatal de atividade econômica em sentido estrito para assegurar imperativos de segurança nacional ou interesse coletivo relevante. $^{46}$

Valendo-nos da classificação de Eros Grau temos que, dentro desse formato, o Estado poderá intervir no domínio econômico de duas formas: (i) por absorção ou (ii) por participação.

Regra geral, as nomenclaturas serão diferentes, mas são constituídas da mesma essência. A intervenção por absorção, de Eros Grau,

\footnotetext{
${ }^{46}$ Silva, José Afonso da. Comentário Contextual à Constituição. $8^{\mathrm{a}}$ ed. São Paulo: Malheiros, 2012. p.732
} 
corresponderá ao monopólio, de José Afonso da Silva e, consequentemente, a intervenção por participação corresponderá ao modelo de intervenção necessária, como proposto por José Afonso.

\subsubsection{INTERVENÇÃO POR ABSORÇÃO}

A intervenção por absorção, segundo os ensinamentos de Eros Grau ocorre quando "o Estado assume o controle de parcela dos meios de produção e/ou troca em determinado setor da atividade econômica em sentido estrito; atua em regime de monopólio". ${ }^{47}$ Ela é equivalente à classificação de Hely Lopes Meirelles para a modalidade de intervenção por regime de monopólio, definida como "a reserva para o Poder Público de determinado setor do domínio econômico" ressaltando que "se a exclusividade for sobre todo o domínio econômico, deixará de ser monopólio para ser estatização da economia privada". ${ }^{48}$.

O monopólio estatal, previsto constitucionalmente no art. 177 atividades no setor de petróleo e gás natural -, deve também compreender, de maneira sistêmica, as atividades previstas no art. 21, incisos VII, X, XI e XII, como por exemplo: a emissão de moeda, serviço postal, de radiodifusão, telecomunicações, infraestrutura aeroportuária, entre outras.

Todas essas atividades monopolizadas estão fora do âmbito da livre iniciativa em seus respectivos setores econômicos. Diferentemente do que ocorre com o monopólio particular, formado pela concentração de poder de mercado, que deve ser coibido pelo Estado ${ }^{49}$, o monopólio estatal de atividade econômica é admitido.

A admissão constitucional, entretanto, é objeto de discórdia entre a doutrina que diverge sobre a redação do art. 173 no que tange à criação de novos monopólios estatais além dos constitucionalmente previstos. A parte

\footnotetext{
${ }^{47}$ GRAU, Eros Roberto. Op. cit. p.143.

${ }^{48}$ MEIRELLES, Hely Lopes. Op. cit. p. 705-706.

${ }^{49} \mathrm{CF}$, art. $174, \S 4^{\circ}$.
} 
da doutrina que defende a possibilidade de criação de novos monopólios entende que o art. 177 é, na verdade, um reflexo dos imperativos de segurança nacional e interesse público que são requeridos pelo art. 173 para que haja atuação do Estado na atividade econômica em sentido estrito.

Ressaltamos aqui que, em relação a este ponto, é indiscutível que (i) o art. 177 se justifica pela proteção das matrizes energéticas do país, o que claramente indica interesse na proteção da segurança nacional, e (ii) o quesito de interesse público é implícito, haja vista a matéria ter sido tratada na Constituição.

Entretanto, esse entendimento doutrinário deve ser analisado com muito cuidado, sob pena de sua interpretação ser levada ao extremo e justificar a criação de novos monopólios apenas em razão da defesa da segurança nacional, como ocorre na interpretação de Eros Grau:

"Parece não restar dúvida não apenas quanto à possibilidade, mas até mesmo à imperiosidade, de a exploração direta da atividade, na hipótese de imperativo de segurança nacional - então definida por lei federal - ser empreendida em regime de monopólio. (...) A definição da situação - como de monopólio ou de participação - na qual atuará diretamente o Estado, na exploração de atividade econômica em sentido estrito, há de ser informada pelo tipo de interesse que a justifique. Na hipótese de imperativo da segurança nacional, o monopólio, em regra, impor-se-á."

Concordamos que a redação do art. 173 não exclui a possibilidade de criação de monopólios em outros setores da economia e tampouco reconhece que as atividades econômicas mencionadas devem ser necessariamente desenvolvidas em regime de concorrência. Mas, ainda assim, entendemos em sentido diverso, considerando que o monopólio representa a eliminação da livre iniciativa em determinado setor econômico, no qual, em princípio, lhe é permitido atuar.

A posição oposta da doutrina está bem declarada nos dizeres de José Afonso da Silva: 
"O monopólio público também ficou bastante limitado, pois já não se declara, como antes, a possibilidade de monopolizar determinada indústria ou atividade. Declara-se a possibilidade de exploração direta de atividade econômica quando necessária aos imperativos da segurança nacional ou relevante interesse coletivo (art. 173). Parece-nos que aí não entra o monopólio, que é reservado só para as hipóteses estritamente indicadas no art. 177 e agora com a flexibilização introduzida pela EC 9/95."

Seguindo a linha de raciocínio proposta pelo autor, a concepção da livre iniciativa, quando exercida no interesse da realização da justiça social é direito fundamental individual, e pode impossibilitar a criação de novos monopólios estatais, inclusive por emenda constitucional, uma vez que essa tentativa representaria uma afronta a direito fundamental protegido como cláusula pétrea ${ }^{51}$.

A intervenção do Estado sob o regime de monopólio tornou-se menos relevante com a recente flexibilização do monopólio estatal no setor petrolífero imposta pela Emenda Constitucional no 9 de 9 de novembro de 1995. A referida emenda permitiu o surgimento de novos instrumentos contratuais para as atividades de produção e exploração de petróleo e deu nova redação ao $\S 1$ do artigo 177 da Constituição, por meio da qual a Petrobrás deixou de ser a única sociedade responsável pela execução do monopólio da União, sendo permitida a contratação de outras sociedades para a realização dessas atividades.

Diante da possibilidade de contratação de sociedades privadas, fezse necessária a criação de mecanismos que viabilizassem a adaptação da Petrobrás ao novo mercado competitivo. Esse novo cenário foi analisado por Luis Roberto Barroso, conforme transcrito abaixo:

\footnotetext{
"Voltando a um terreno de sistematização, essa transformação do Estado econômico brasileiro envolve três coisas distintas, que, em geral, são tratadas de forma um pouco embaralhada. A transformação econômica do Estado brasileiro envolve, em primeiro lugar, a quebra de determinados monopólios. As emendas constitucionais quebraram o monopólio do petróleo e quebraram, por exemplo, o monopólio na área de telecomunicações; quebraram o monopólio sem alienar a empresa estatal que o explorava. Significa criar um modelo pelo qual a
}

\footnotetext{
${ }^{50}$ SILVA, José Afonso da. Op. cit. 2011, p. 807-808.

${ }^{51} \mathrm{CF}$, art. $60, \S 4^{\circ}, \mathrm{IV}$.
} 
empresa estatal - que explora uma atividade - vai passar a concorrer com outras empresas, estas privadas, exploradoras da mesma atividade. A Petrobrás vai ter concorrentes explorando e vendendo petróleo no segmento de distribuição. Esse não é um setor monopolizado, como se sabe. E a Embratel vai passar a ter concorrência. Portanto, a primeira transformação importante é: quebra-se o monopólio, mas mantém-se a empresa estatal. Essa é a hipótese 1. A empresa estatal vai ter de aprender a viver num regime de concorrência, de competição. Não deixa de ser boa a idéia de que os monopólios sejam quebrados e existam empresas privadas concorrendo com as empresas estatais." ${ }^{\natural 2}$ (grifos nossos)

A flexibilização não alcança o monopólio sobre os bens (previstos no art. 20) que são objeto da atividade flexibilizada, mas apenas e tão somente a execução das atividades, quais sejam pesquisa, lavra, refino, importação e exportação e transporte do petróleo e gás natural.

A EC no 9/95 também altera o regime jurídico das empresas estatais que atuavam como exploradoras do monopólio, passando a atuar em regime de concorrência com as demais empresas privadas. Isso porque elas passaram a se enquadrar no regime privado previsto no inciso II, $\S 1^{\circ}$ e $\S 2^{\circ}$ do art. 173. O entendimento do Supremo Tribunal Federal segue a mesma linha:

EMENTA: CONSTITUCIONAL. MONOPÓLIO. CONCEITO E CLASSIFICAÇÃO. PETRÓlEO, GÁS NATURAL E OUTROS HIDROCARBONETOS FLUÍDOS. BENS DE PROPRIEDADE EXCLUSIVA DA UNIÃO. ART. 20, DA CB/88. MONOPÓLIO DA ATIVIDADE DE EXPLORAÇÃO DO PETRÓLEO, DO GÁS NATURAL E DE OUTROS HIDROCARBONETOS FLUÍDOS. ART. 177, I a IV e $§ 1^{\circ}$ E $2^{\circ}$, DA CB/88. REGIME DE MONOPÓLIO ESPECÍFICO EM RELAÇÃO AO ART. 176 DA CONSTITUIÇÃO. DISTINÇÃO ENTRE AS PROPRIEDADES A QUE RESPEITAM OS ARTS. 177 E 176, DA CB/88. PETROBRAS. SUJEIÇÃO AO REGIME JURÍDICO DAS EMPRESAS PRIVADAS [ART. 173, § $1^{\circ}$, II, DA CB/88]. EXPLORAÇÃO DE ATIVIDADE ECONÔMICA EM SENTIDO ESTRITO E PRESTAÇÃO DE SERVIÇO PÚBLICO. ART. 26, § 3, DA LEI N. 9.478/97. MATÉRIA DE LEI FEDERAL. ART. 60, CAPUT, DA LEI N. 9.478/97. CONSTITUCIONALIDADE. COMERCIALIZAÇÃO ADMINISTRADA POR AUTARQUIA FEDERAL [ANP]. EXPORTAÇÃO AUTORIZADA SOMENTE SE OBSERVADAS AS POLÍTICAS DO CNPE, APROVADAS PELO PRESIDENTE DA REPÚBLICA [ART. 84, II, DA CB/88]. 1. O conceito de monopólio pressupõe apenas um agente apto a desenvolver as atividades econômicas a ele correspondentes. Não se presta a explicitar

\footnotetext{
${ }^{52}$ BARROSO, Luís Roberto. A Intervenção do Estado no Domínio Econômico - O Estado como agente normativo e regulador na exploração de atividades econômicas e na prestação de serviços públicos. Disponível em <www.zenite.com.br>. Acesso em 04 de nov. 2012
} 
características da propriedade, que é sempre exclusiva, sendo redundantes e desprovidas de significado as expressões "monopólio da propriedade" ou "monopólio do bem". 2. Os monopólios legais dividem-se em duas espécies: (i) os que visam a impelir o agente econômico ao investimento --- a propriedade industrial, monopólio privado; e (ii) os que instrumentam a atuação do Estado na economia. 3. A Constituição do Brasil enumera atividades que consubstanciam monopólio da União [art. 177] e os bens que são de sua exclusiva propriedade [art. 20]. 4. A existência ou o desenvolvimento de uma atividade econômica sem que a propriedade do bem empregado no processo produtivo ou comercial seja concomitantemente detida pelo agente daquela atividade não ofende a Constituição. $\mathrm{O}$ conceito de atividade econômica [enquanto atividade empresarial] prescinde da propriedade dos bens de produção. (...) 14. A Petrobras não é prestadora de serviço público. Não pode ser concebida como delegada da União. Explora atividade econômica em sentido estrito, sujeitando-se ao regime jurídico das empresas privadas [ $\S 1^{\circ}$, II, do art. 173 da $\left.\mathrm{CB} / 88\right]$. Atua em regime de competição com empresas privadas que se disponham a disputar, no âmbito de procedimentos licitatórios [art. 37, XXI, da CB/88], as contratações previstas no $\S 1^{\circ}$ do art. 177 da Constituição do Brasil..$^{53}$

\subsubsection{INTERVENÇÃO POR PARTICIPAÇÃO}

A intervenção por participação ou necessária, na classificação de José Afonso da Silva, será aquela em que o Estado intervém na atividade econômica em sentido estrito, na forma do art. 173 da CF. Nos dizeres de Eros Grau:

"Quando o faz por participação, Estado assume o controle de parcela dos meios de produção e/ou troca em determinado setor da atividade econômica em sentido estrito; atua em regime de competição com empresas privadas que permanecem a exercitar suas atividades nesse mesmo setor." ${ }^{54}$

Essa modalidade de intervenção implica em larga interpretação do art. 173 - seu fundamento constitucional - que já foi objeto de nosso estudo no item 4.1 acima. De toda forma, aqui abordaremos situações concretas e os resultados efetivos atingidos pela intervenção por participação.

Primeiramente, vale relembrar mais uma vez que a prestação de serviços públicos, embora possa ser considerada atividade econômica por gerar lucros, não será considerada intervenção, uma vez que o Estado, neste caso, atua em campo que ele próprio é titular e, logo, não intervém.

\footnotetext{
${ }^{53}$ STF, ADI n. 3.366/DF, Rel. Min. Carlos Britto, Brasília, 16.03.2005, Tribunal Pleno.

${ }^{54}$ GRAU, Eros Roberto. Op. cit. p.143.
} 
As atividades econômicas em sentido estrito tanto são distintas das atividades de prestação de serviços públicos que o regime jurídico a elas aplicável é distinto. Vejamos as anotações de Maria Sylvia Di Pietro sobre a inaplicabilidade do art. 173 às empresas estatais ou concessionárias que prestam serviço público:

\begin{abstract}
“(...) como o artigo 173 cuida especificamente da atividade de natureza privada, exercida excepcionalmente pelo Estado por razões de segurança nacional ou interesse coletivo relevante, há que se concluir que as normas dos $\S \S 1^{\circ}$ e $2^{\circ}$ só incidem nessa hipótese. Se a atividade for econômica (comercial ou industrial), mas assumida pelo Estado como serviço público, tais normas não têm aplicação, incidindo, então, o artigo 175 da Constituição, segundo o qual incumbe ao Poder Público, na forma da lei, diretamente ou sob regime de concessão ou permissão, sempre através de licitação, a prestação de serviços públicos." 55
\end{abstract}

Embora a intervenção por participação seja excepcional e permitida apenas quando justificados os imperativos de segurança nacional e interesse coletivo, é relativamente ampla a gama de entidades estatais que desenvolvem atividades econômicas nesse regime, principalmente no setor financeiro, como, por exemplo, Banco do Brasil, Caixa Econômica Federal, Cobra Tecnologia, Alcântara Cyclone Space (empresa binacional Brasil Ucrânia), entre outras.

Todas as entidades estatais que atuam em setores privados, reservados inicialmente à iniciativa privada, estão sob regime de livre concorrência, competindo com os demais agentes econômicos. Essa regra é extremamente necessária até para garantir que não haverá concorrência desleal, estando também sujeitas às regulamentações específicas do setor econômico em que atuam. Nesse sentido, o Estado Empresário deverá também se subordinar ao Estado Regulador.

Exatamente por estarem em regime de concorrência com as demais empresas privadas, as entidades estatais costumam atuar como instrumentos do governo para garantir a eficácia de suas medidas. Um recente exemplo

\footnotetext{
${ }^{55}$ DI PIETRO, Maria Sylvia Zanella. Direito Administrativo. $23^{\mathrm{a}}$ ed. São Paulo: Atlas, 2010. p. 444-445.
} 
foi o corte na taxa de juros praticados pelas instituições financeiras. Os trechos das reportagens abaixo, retirados dos sites "O Globo" e "G1" retratam claramente a pressão do governo, através das instituições financeiras a ele vinculadas, para forçar a queda de juros praticada pelas demais:

(i) "BANCOS BRASILEIROS JÁ PERDERAM US\$ 17,4 BILHÕES EM VALOR DE MERCADO ESTE ANO. SÃO PAULO - (...) Este ano, as ações dos bancos brasileiros foram castigadas na Bolsa com as ações do governo para reduzir o spread (ganhos) das instituições. Usando o Banco do Brasil e a Caixa Econômica para reduzir juros de empréstimos, o governo forçou os bancos privados a também baixarem seus valores. Agora, o próximo alvo é a redução de tarifas bancárias cobradas pelas instituições. Até agora, o Itaú Unibanco foi o único banco privado a reduzir tarifas." 56

(ii) "SOB PRESSÃO, BANCOS REDUZEM JUROS; VEJA AS TAXAS MÉDIAS COBRADAS. Taxa média de juros bancários está no menor nível da história, segundo BC. Especialistas dizem que governo usou bancos públicos para forçar situação.

Para Carlos Stempniewski, professor de finanças no curso de administração das Faculdades Rio Branco, há um cenário político por trás do movimento. "[O governo] Começou a injetar dinheiro na Caixa para que pudesse emprestar e também forçou um pouco o Banco do Brasil. Também injetou dinheiro no BNDES para financiar os empresários e começou a forçar por aî", diz. (...) Para o professor, tornou-se evidente a transferência significativa do volume de crédito dentro do sistema bancário. "As pessoas começaram a financiar através dos bancos ligados ao governo em detrimento do privado. Só que banqueiro vive de juro. Ele precisa emprestar, senão, não consegue ter lucro." ${ }^{, 57}$ (grifos nossos)

Nesse mesmo sentido, versa Carlos Ari Sundfeld sobre a atuação das empresas estatais como instrumentos da ação governamental:

\footnotetext{
"as estatais de intervenção no domínio econômico são também instrumentos de ação governamental, exigida por 'imperativos da segurança nacional ou relevante interesse coletivo'. O Estado não as cria para investir, buscando simples lucros, mas sempre para implementar políticas públicas (o desenvolvimento regional, a construção de habitações populares, o financiamento agrícola, etc.).

Daí, então, dizer que as empresas estatais desenvolvem ação governamental, apesar de revestirem o chamado 'figurino privado' (a forma empresarial, adotada

${ }^{56}$ Bancos brasileiros já perderam US\$17,4 bilhões em valor de mercado este ano. Disponível em $<$ www.oglobo.com.br>. Acesso em 6 nov. 2012.

${ }^{57}$ Glenia, Fabíola. Sob pressão, bancos reduzem juros; veja as taxas médias cobradas. Disponível em <www.g1.com.br>. Acesso em 6 nov. 2012.
} 
pelas sociedades mistas e empresas públicas) e, em algumas hipóteses, explorarem atividades econômicas." ${ }^{\text {58 }}$

\subsection{INTERVENÇÃO INDIRETA}

A intervenção indireta é aquela que reflete as funções do Estado Regulador, atuando sempre em conformidade com o fundamento constitucional previsto no art. 174 da Constituição.

$\mathrm{Na}$ intervenção indireta o Estado intervém sobre o domínio econômico, impondo regras que podem ser compulsórias ou apenas influenciadoras de comportamento. É através dessa modalidade de intervenção que o Estado efetivamente controla e gerencia a atividade privada norteando-a de acordo com os planos de desenvolvimento do país.

A intervenção indireta subdivide-se, em relação à coercitibilidade de suas normas, em: (i) intervenção por direção; e (ii) intervenção por indução. A nomenclatura dessa classificação pode sofrer alterações, sendo referidas como "disciplina" e "fomento", na maioria das vezes.

Alguns autores, como José Afonso da Silva ${ }^{59}$, entendem que a regulação, e principalmente a fiscalização - função do Estado Regulador -, não deveriam ser estudadas como intervenção do Estado sobre o domínio econômico porque, na verdade, o Estado estaria exercendo o seu poder de polícia.

Para a análise da intervenção do Estado, tomaremos por base o fato de que o Estado tem o poder-dever de regular e a função de fiscalizar e que, quando o faz, se utiliza do seu poder de polícia. O poder de polícia é o meio coercitivo utilizado pelo Estado para realizar suas funções, mas com elas não se confunde.

\footnotetext{
${ }^{58}$ SUNDFELD, Carlos Ari. Reforma do Estado e Empresas Estatais. In: SUNDFELD, Carlos Ari et al. Direito Administrativo Econômico. São Paulo: Malheiros, 2002. p. 264-285.

${ }^{59}$ SILVA, José Afonso da. Op. cit., 2011, p. 809.
} 
Ademais, vale relembrar que a intervenção indireta se concretiza, via de regra, por atos administrativos de entidades reguladoras que, contudo, não poderão se efetivar sem a respectiva previsão legal que os fundamente. As entidades reguladoras não devem ser compreendidas aqui como autarquias federais apenas, isso porque qualquer órgão vinculado à Administração Pública direta poderá fazê-lo, dentro do regime de competências previsto na Constituição. Assim, quando o art. 174 se refere ao poder-dever regulador do Estado, ele quer abranger toda a competência federal, estadual e municipal sobre o tema.

\subsubsection{INTERVENÇÃO POR DIREÇÃO}

$\mathrm{Na}$ intervenção por direção o Estado pressiona a economia, impondo mecanismos e normas de comportamento para os agentes econômicos que desenvolvem atividade econômica em sentido estrito. Segundo José Afonso da Silva, essa pressão exercida pelo Estado surgiu para devolver a atividade econômica à sua normalidade, em defesa da livre concorrência. ${ }^{60}$ Ocorre que, com a evolução do Estado, essas normas foram se proliferando em diversas outras áreas, inclusive para defender princípios sociais que estão dentro dos princípios constitucionais econômicos, como vimos no capítulo 2.

As normas de intervenção por direção são comandos imperativos, normas cogentes que impõem determinados comportamentos aos particulares. As normas de direção são compulsórias e todos os agentes da atividade econômica em sentido estrito estão obrigados a cumpri-las, sob pena de serem sancionados. Ressalte-se que quando as normas diretivas impuserem limitações aos particulares elas só poderão fazê-lo por regulamentação legal.

\footnotetext{
${ }^{60}$ SILVA, José Afonso da. Op. cit. 2012, p. 736.
} 
As práticas mais comuns de intervenção por indução se refletem no controle de atos de concentração, no tabelamento, congelamento e controle de preços e abastecimento, e diversas outras normas que, fora do âmbito dos serviços públicos, implicam para o particular (e o Estado, quando este intervém por participação) obrigações que podem até onerá-los.

O $\S 4^{\circ}$ do art. 173 da Constituição disciplina a atuação do órgão estatal para coibir o abuso de poder econômico em defesa da livre iniciativa e livre concorrência. Embora a função desempenhada pelo Estado não se enquadre na modalidade de intervenção direta, pois não estaria atuando como agente econômico, a afirmação de que essa atividade estaria inserida no rol das intervenções indiretas por direção também não é integralmente correta.

O Conselho Administrativo de Defesa Econômica (CADE), autarquia federal responsável por analisar atos de concentração e investigar, prevenir e fiscalizar infrações à ordem econômica, pratica atos vinculados, utilizando-se de seu poder de polícia, mas sem discricionariedade para regular sobre o mercado. Ao revés, ele deve ser o guardião do mercado, da livre concorrência.

Ademais, a intervenção por direção do art. 174 implica em certo grau de discricionariedade na regulação, o que não ocorre com o CADE onde os atos, em regra, são vinculados. Há, entretanto, uma exceção: a imposição de restrições às transações comerciais submetidas à sua aprovação. Aqui, ao estabelecer as medidas restritivas, o CADE possui discricionariedade e, nesse caso, haverá intervenção, mesmo que para proteger o mercado. Fora isso, ele apenas se utiliza de seu poder de polícia.

A regulação da ordem econômica, de acordo com Carlos Ari Sundfeld: 
"manifesta-se tanto por poderes e ações com objetivos declaradamente econômicos (o controle de concentrações empresariais, a repressão de infrações à ordem econômica, (...)) como por outros com justificativas diversas, mas efeitos econômicos inevitáveis (medidas ambientais, urbanísticas, (...))., ${ }^{, 61}$

Feitas as ressaltas em relação ao controle de atos de concentração realizado pelo CADE, a definição de Carlos Ari Sundfeld é bem justa, porque compreende inclusive outros regulamentos compulsórios que também geram efeitos econômicos. A regulação, entretanto, não pode ser desarrazoada, em prejuízo dos particulares que exercem suas atividades. Ela deve servir aos fins para os quais foi criada, tendo por certo que não pode causar mais dano do que o bem que se pretende tutelar.

O tabelamento de preços, por exemplo, é mecanismo utilizado pelo Estado para coibir abusos econômicos, mas nem sempre ele é utilizado corretamente, gerando graves danos ao setor privado e ao princípio constitucional da livre iniciativa. Em julgamento no Supremo Tribunal Federal sobre o tabelamento de preços do setor sucroalcooleiro pelo Instituto de Álcool e do Açúcar (IAA), o Ministro Carlos Velloso assim se pronunciou:

"De fato, o texto constitucional de 1988 é claro ao autorizar a intervenção estatal na economia, por meio da regulamentação e da regulação de setores econômicos. Entretanto, o exercício de tal prerrogativa deve se ajustar aos princípios e fundamentos da Ordem Econômica, nos termos do art. 170 da Constituição.

Assim, a faculdade atribuída ao Estado de criar normas de intervenção estatal na economia (...) não autoriza a violação ao princípio da livre iniciativa, fundamento da República (art. $1^{\circ}$.) e da Ordem Econômica (art. 170, caput).

No caso, a fixação de preços a serem praticados pela Recorrente, por parte do Estado, em valores abaixo da realidade e em desconformidade com a legislação aplicável ao setor constitui-se em empecilho ao livre exercício da atividade econômica, em desrespeito ao princípio da liberdade de iniciativa.

Ademais, o estabelecimento de regras bem definidas de intervenção estatal na economia e sua observância são fundamentais para o amadurecimento das instituições e do mercado brasileiros, proporcionando a necessária estabilidade econômica que conduz ao desenvolvimento nacional." ${ }^{\text {"2 }}$ (grifos nossos)

\footnotetext{
${ }^{61}$ SUNDFELD, Carlos Ari.Op. cit. p. 18.

${ }^{62}$ STF, RE 422.941/DF, Rel. Min. Carlos Velloso, Brasília, 6 dez. 2005.
} 
Na mesma linha, o Superior Tribunal de Justiça assim se manifestou a respeito da possibilidade de imputar à iniciativa privada obrigação mais onerosa do que a necessária para o desenvolvimento normal da atividade:

"TRANSPORTE. FISCAIS DO TRABALHO. PASSE LIVRE. LINHA SELETIVA. IMPOSSIBILIDADE. A obrigatoriedade da concessão da gratuidade legal é apenas no tocante ao transporte comum, não se estendendo o referido benefício ao transporte seletivo, que conduz um número menor de passageiros, dispondo de comodidades como ar-condicionado, televisão, som ambiente, que o serviço comum não possui, e uma tarifa maior em razão do diferencial do serviço prestado. É excepcional a intervenção do Estado no domínio econômico, no sistema de livre iniciativa. Tal intervenção há de se pautar pela razoabilidade, que, no caso, recomenda que a concessão de passe livre aos fiscais do trabalho mantenha a finalidade de viabilizar o bom andamento do seu serviço sob o abrigo do princípio da menor onerosidade possível. Havendo linhas regulares, com o mesmo itinerário, não há razão para que os fiscais utilizem-se gratuitamente de um serviço prestado seletivamente. $\underline{O}$ fato de a lei conceder a esses servidores a possibilidade de deslocamento, não significa que deva ser no meio de transporte mais oneroso." ${ }^{, 63}$ (grifos nossos)

\subsubsection{INTERVENÇÃO POR INDUÇÃO}

$\mathrm{Na}$ intervenção por indução o Estado se utiliza de mecanismos jurídicos não coercitivos para manipular o funcionamento dos mercados. Essa modalidade de intervenção é equivalente ao fomento.

A indução, exatamente como o vocábulo aduz, terá carga coercitiva inferior ao da intervenção por direção. Quem dirige detém o controle, quem induz não tem controle porque depende da aderência do setor privado, que é facultativa. Dessa forma, a intervenção indutiva só se concretiza, com efeitos na economia, quando o particular voluntariamente concorda com a proposta estatal.

Sobre a essa modalidade de intervenção, destaca-se a percepção de Eros Grau a respeito da coercitibilidade das normas de indução:

"No caso das normas de intervenção por indução defrontamo-nos com preceitos que, embora prescritivos (deônticos), não são dotados da mesma carga de cogência que afeta as normas de intervenção por direção. Trata-se de normas

\footnotetext{
${ }^{63}$ STJ, Informativo STJ n. 189, out/2003, REsp 443.310/ RS, Rel. Min. Luiz Fux, Brasília, 21 out. 2003.
} 
dispositivas. Não, contudo, no sentido de suprir a vontade dos seus destinatários, porém, na dicção de Modesto Carvalhosa, no de 'levá-lo a uma opção econômica de interesse coletivo e social que transcende os limites do querer individual'. Nelas, a sanção, tradicionalmente manifestada como comando, é substituída pelo expediente do convite (...) Ao destinatário da norma resta aberta a alternativa de não se deixar por ela seduzir, deixando de aderir à prescrição nela veiculada. Se adesão a ela manifestar, no entanto, resultará juridicamente vinculado por prescrições que correspondem aos benefícios usufruídos em decorrência dessa adesão." 64

A norma de indução pode ser tanto positiva como negativa, no sentido de incentivar um determinado comportamento ou onerá-lo para que se torne menos atrativo. Acerca das normas de indução negativas, Eros Grau, em posição mais radical, considera que o efeito dessas normas é tornar a atividade economicamente proibitiva:

“Também há norma de intervenção por indução quando o Estado, v.g., onera por imposto elevado o exercício de determinado comportamento, tal como no caso de importação de certos bens. A indução, então, é negativa. A norma não proíbe a importação desses bens, mas a onera de tal sorte que ela se torna economicamente proibitiva."

Cumpre-nos salientar que é este o maior perigo da modalidade de intervenção por indução: tornar a atividade economicamente inviável. Ou seja, a norma indutiva formalmente não proíbe a atividade regulada, mas a falta de razoabilidade da medida indutiva torna a atividade inviável, o que funciona como uma proibição.

A princípio, com a aplicação da norma indutiva negativa, a atividade econômica seria mais desvantajosa em comparação com outras do mesmo mercado (e isso implicaria em menor lucratividade), mas a norma indutiva não poderia nunca torná-la inviável. O resultado da indução não pode ser a proibição de determinada atividade, pois não é essa a natureza da norma indutiva. Ela deveria ser apenas e tão somente norteadora de comportamentos.

\footnotetext{
${ }^{64}$ GRAU, Eros Roberto. Op. cit. p. 144-145.
} 
Como exemplo de tais medidas desproporcionais, temos o recente aumento da alíquota do Imposto sobre Produtos Industrializados para automóveis importados.

O Ministro Celso de Mello, em medida cautelar da ADI questionando a constitucionalidade do Decreto presidencial $\mathrm{n}^{0} 7.567 \mathrm{de}$ 15/09/2011, que majorava alíquota de Imposto sobre Produtos Industrializados para automóveis importados, assevera:

"A controvérsia instaurada na presente causa sugere e estimula reflexões que me levam, uma vez mais, a reafirmar, na linha de decisões que proferi nesta Suprema Corte (RTJ 144/435-436, Rel. Min. CELSO DE MELLO - RE 428.354/RS, Rel. Min. CELSO DE MELLO, v.g.), que os desvios inconstitucionais do Estado, no exercício do seu poder de tributar, geram, na ilegitimidade desse comportamento do aparelho governamental, efeitos perversos, que, projetando-se nas relações jurídico-fiscais mantidas com os contribuintes, deformam os princípios que estruturam a ordem jurídica, subvertem as finalidades do sistema normativo e comprometem a integridade e a supremacia da própria Constituição da República.

Cumpre assinalar, por isso mesmo, que o caso ora em exame justifica, plenamente, que se reiterem tais asserções, pois é necessário advertir que a prática das competências impositivas por parte das entidades políticas investidas da prerrogativa de tributar não pode caracterizar-se como instrumento, que, arbitrariamente manipulado pelas pessoas estatais, venha a conduzir à destruição ou ao comprometimento da própria ordem constitucional. (...)

Cabe relembrar, neste ponto, consideradas as observações que venho de fazer, a clássica advertência de OROSIMBO NONATO, consubstanciada em decisão proferida pelo Supremo Tribunal Federal (RE 18.331/SP), em acórdão no qual aquele eminente e saudoso Magistrado acentuou, de forma particularmente expressiva, à maneira do que já o fizera o Chief Justice JOHN MARSHALL, quando do julgamento, em 1819, do célebre caso "McCulloch $v$. Maryland", que "o poder de tributar não pode chegar à desmedida do poder de destruir" (RF 145/164 - RDA 34/132), eis que - como relembra BILAC PINTO, em conhecida conferência sobre "Os Limites do Poder Fiscal do Estado" (RF $82 / 547-562,552)$ - essa extraordinária prerrogativa estatal traduz, em essência, "um poder que somente pode ser exercido dentro dos limites que o tornem compativel com a liberdade de trabalho, de comércio e de indústria e com o direito de propriedade" (grifei)." 65 (grifos no original)

Em regra, o Estado se utiliza de tributos extrafiscais para concretizar as medidas indutivas. Os tributos extrafiscais almejam a persecução de

\footnotetext{
${ }^{65}$ STF, ADI 4.661 MC/DF, Rel. Min. Marco Aurélio, Brasília, 20 out. 2011. Tribunal Pleno. Voto do Min. Celso de Mello.
} 
objetivos que não a simples arrecadação, e buscam corrigir anomalias. Entre os inúmeros tributos que podem ser utilizados para este fim, cabe ressaltar que a Constituição prevê (art. 149) a criação de um tributo exclusivamente para intervir na economia: a Contribuição de Intervenção no Domínio Econômico (CIDE).

A CIDE tem sido um dos maiores instrumentos do Estado para interferir no preço da gasolina e, com isso, reter a inflação. Como o preço dos combustíveis integram o cálculo da inflação, o governo se utiliza de todos os meios (leia-se CIDE e Petrobras) para frear a inflação.

No caso dos combustíveis, especialmente, o Estado atua de duas maneiras, ora utilizando-se de seu poder de controle para forçar a Petrobras a reduzir o preço dos combustíveis (intervenção por participação), ora reduz a CIDE (intervenção por indução).

Por fim, mas não menos importante, a União atua na economia através do Banco Nacional de Desenvolvimento Econômico e Social (BNDES). O BNDES possui programas de financiamento para as mais diversas atividades como os repasses para a renovação do parque industrial, a realização de obras de infraestrutura e a produção de filmes. Com uma vasta área de atuação, é o banco que empresta com os menores juros, as formas de pagamento mais favoráveis e muitos outros benefícios que encantam o setor privado.

O papel de fomento do desenvolvimento econômico é inquestionável. Contudo, para que o particular possa usufruir desses benefícios o governo exige uma contrapartida. E é nas regras gerais aplicáveis aos programas de financiamento do BNDES que se configura outra forma de intervenção. São cláusulas contratuais obrigando o particular a estar em dia com uma série de normativos ambientais, trabalhistas e 
tributários, sob pena de ter sua dívida declarada vencida antecipadamente ou de ter seu benefício revogado, vejamos:

"Art. 34 - A Beneficiária da Colaboração Financeira obriga-se a: (...)

$\mathrm{X}$ - cumprir as exigências do BNDES e de autoridades federais, estaduais e municipais, relativas à preservação do meio ambiente;

XI - não contratar serviços de pessoas físicas ou jurídicas situadas fora do País, salvo para funções ou atividades altamente técnicas e especializadas, inexistentes ou carentes no País, ou que constituam know how introduzido pelo projeto apoiado pelo BNDES;

(...)

XIV - manter em dia o pagamento de todas as obrigações de natureza tributária, trabalhista, previdenciária, e outras, de caráter social, inclusive o recolhimento das contribuições devidas ao Fundo de Participação PIS/Pasep e ao Fundo de Investimento Social - Finsocial, exibindo ao BNDES os respectivos comprovantes, sempre que exigidos, bem como apresentar, se assim exigida, prova idônea do cumprimento de obrigação de qualquer outra natureza a que esteja submetida por força de disposição legal ou regulamentar," 66

\footnotetext{
${ }^{66}$ Resolução BNDES 665/87. Disponível em <www.bndes.gov.br>. Acesso em 8 nov. 2012.
} 


\section{CONCLUSÃO}

Tendo estudado a evolução do papel do Estado na economia, bem como o desenvolvimento da ordem econômica constitucional brasileira, percebemos que (i) a sociedade brasileira não vivenciou o liberalismo, e (ii) nosso país se desenvolveu sob uma forte influência intervencionista.

Ao examinarmos o art. 170, verificamos que a própria Constituição adota a livre iniciativa e a livre concorrência como princípios constitucionais econômicos instrumentais que devem ser utilizados para se atingir os princípios-fins almejados. Mais ainda, percebemos que o constituinte optou por um sistema de economia de mercado com toques de intervenção social, quase um sistema misto de liberalismo econômico e intervencionismo.

Para assegurar o cumprimento desses princípios, a Constituição municiou o Estado com duas formas de intervenção na economia: direta e indireta. $\mathrm{O}$ ente estatal recebeu instrumentos para ordenar a economia de acordo com as políticas econômicas e sociais formuladas em prol do desenvolvimento do país. Passamos a refletir, então, sobre as modalidades e a intensidade dessas intervenções no domínio econômico.

Com relação à intervenção direta, a Constituição de 1988 impôs limites específicos à atuação do Estado como explorador de atividades econômicas, que só poderá fazê-lo caráter excepcional. A intervenção indireta, por outro lado, não possui balizas constitucionais tão rígidas, deixando ao Estado Regulador a conveniência e oportunidade de regular.

Tendo em vista o papel do Estado como organizador e regulador da economia, é importante que ele atue eficientemente e desenvolva políticas coerentes com os objetivos a serem alcançados pela sociedade brasileira, utilizando-se dos instrumentos concedidos pela Constituição de 1988 de forma a garantir o desenvolvimento sustentável do país e a justiça social. 
O limite da intervenção do Estado está claramente na aplicação correta e ponderada dos princípios constitucionais econômicos, guiando a livre iniciativa e livre concorrência no sentido de uma sociedade mais justa.

Entendemos, por fim, que a reflexão crítica sobre o papel do Estado e seus limites é um exercício de cada cidadão em benefício de sua própria liberdade. O questionamento faz com que não aceitemos de pronto as limitações como nos são apresentadas. Não sem antes, ao menos, fazermos um julgamento crítico sobre o que nos foi imposto. 


\section{BIBLIOGRAFIA}

Alvará de $1^{\circ}$ de Abril de 1808. Disponível em <http://www.planalto.gov.br>. Acesso em 6 de nov. 2012.

Bancos brasileiros já perderam US\$17,4 bilhões em valor de mercado este ano. Disponível em <www.oglobo.com.br>. Acesso em 6 nov. 2012.

BARROSO, Luís Roberto. A Ordem Econômica Constitucional e os Limites à Atuação Estatal no Controle de Preços. Revista de Direito Administrativo, Rio de Janeiro, v. 226, p.187-212, out/dez 2001. Trimestral.

CARVAlHO FILHO, José dos Santos. Manual de Direito Administrativo. 23 ed. Rio de Janeiro: Lumen Juris, 2010. p. 987.

CRISTOFARO, Pedro Paulo Salles. Comentários ao art. 36, inciso III da Lei 12.529/2012. (artigo ainda não publicado)

DI PIETRO, Maria Sylvia Zanella. Direito Administrativo. $23^{\mathrm{a}}$ ed. São Paulo: Atlas, 2010. 875p.

GLENIA, Fabíola. Sob pressão, bancos reduzem juros; veja as taxas médias cobradas. Disponível em <www.g1.com.br>. Acesso em 6 nov. 2012.

GRAU, Eros Roberto. A Ordem Econômica na Constituição de 1988. 15a. ed. São Paulo: Malheiros, 2012. 383 p.

JUSTEN FILHO, Marçal. O Direito Regulatório. Interesse Público: Fórum. Belo Horizonte, n. 43, p. 19-40, 2007

LENZA, Pedro. Direito Constitucional Esquematizado. 15 ed. São Paulo: Saraiva, 2011 
MANKIW, Gregory N. Introdução a Economia. São Paulo: Pioneira Thomson, 2011.

MEIRELLES, Hely Lopes. Direito Administrativo Brasileiro. $38^{\text {a }}$ ed. São Paulo: Malheiros, 2012. 910 p.

MELLO, Celso Antônio Bandeira de. Curso de Direito Administrativo. $28^{\mathrm{a}}$ ed. São Paulo: Malheiros, 2011. 1127 p.

Pareceres de Direito Administrativo. São Paulo: Malheiros, 2011. $456 \mathrm{p}$.

MONCADA, Luís S. Cabral de. Direito Econômico. $5^{\mathrm{a}}$ ed. Coimbra: Coimbra Editora, 2007.

MORAES, Alexandre de. Constituição do Brasil Interpretada e Legislação Constitucional. São Paulo: Atlas, 2011. 2402 p.

NEVES, Rodrigo Santos. O Estado Regulador: a dignidade humana como princípio informador da regulação do mercado. Revista Forense, Rio de Janeiro, v. 377, n. , p.205-221, 2005.

RAMOS FILHO, Carlos Alberto de Moraes. A intervenção do Estado no domínio econômico: limites e modalidades à luz do direito brasileiro. Revista Tributária e de Finanças Públicas, Rio de Janeiro, v. 17, n. 88, p.60-90, 2009.

REALE, Miguel. Plano Collor II e a Intervenção do Estado na Ordem Econômica. Revista de Direito Bancário e do Mercado de Capitais, São Paulo, n. , p.311-322, 2011.

SAMPAIO, Alexandre Ribeiro. Notas essenciais sobre o modelo brasileiro de Estado regulador: Antecedentes históricos e formato adotado. Revista Forense, Rio de Janeiro, n. 414, p.423-445, 2011. 
SILVA, José Afonso da. Comentário Contextual à Constituição. $8^{\mathrm{a}}$ ed. São Paulo: Malheiros, 2012. p.732

Curso de Direito Constitucional Positivo. $34^{\mathrm{a}}$ ed. São Paulo: Malheiros, 2011. 928 p.

STF, ADI n. 319/QO, Rel. Min. Moreira Alves, Brasília, 3 mar.1993.

STF, ADI n. 3.366/DF, Rel. Min. Carlos Britto, Brasília, 16.03.2005, Tribunal Pleno.

STF, RE 407.099/RS, Rel. Min. Carlos Velloso, Brasília, 22 jun. 2004

SUNDFELD, Carlos Ari et al. (Org.). Direito Administrativo Econômico. 2. ed. São Paulo: Malheiros, 2002.

VENÂNCIO FILHO, Alberto. A Intervenção do Estado no Domínio Econômico. Rio de Janeiro: Renovar, 1968.

VICENTINO, Claudio; DORIGO, Gianpaolo. História do Brasil. São Paulo: Scipione, 1997. 504 p. 